\title{
A New $\mathrm{Cr}^{3+}$ Electrochemical Sensor Based on ATNA/Nafion/Glassy Carbon Electrode
}

\author{
Reda M. El-Shishtawy ${ }^{1, * \mathbb{C}}$, Mohammed M. Rahman ${ }^{1, * \mathbb{C}}$, Tahir Ali Sheikh ${ }^{2}{ }^{\mathbb{C}}$, \\ Muhammad Nadeem Arshad ${ }^{1}$ (D), Fatimah A. M. Al-Zahrani ${ }^{3}$ and Abdullah M. Asiri ${ }^{1}$ (D) \\ 1 Chemistry Department, Faculty of Science, King Abdulaziz University, Jeddah 21589, Saudi Arabia; \\ mnachemist@hotmail.com (M.N.A.); aasiri2@kau.edu.sa (A.M.A.) \\ 2 Irrigation Research Institute, Irrigation Department, Government of the Punjab, Old Anarkali, \\ Lahore-54000, Pakistan; tahirgcu786@gmail.com \\ 3 Chemistry Department, Faculty of Science, King Khalid University, P.O. Box 9004, Abha 61413, Saudi Arabia; \\ falzhrani@kku.edu.sa \\ * Correspondence: relshishtawy@kau.edu.sa (R.M.E.-S.); mmrahman@kau.edu.sa (M.M.R.)
}

Received: 21 April 2020; Accepted: 11 June 2020; Published: 12 June 2020

check for updates

\begin{abstract}
A new electrochemical sensor of metal cation in an aqueous solution based on homobifunctional tridentate disulfide Schiff base and named 1,1'-(-((disulfanediylbis(2,1-phenylene)) bis(azaneylylidene))bis(methaneylylidene))bis(naphthalene-2-ol) (ATNA) was easily obtained quantitatively from the condensation reaction of 2-hydroxy-1-naphthaldehyde and 2-aminothiophenol, and then fully characterized by spectroscopic techniques for structure elucidation. The molecular structure of ATNA was also confirmed by a single-crystal X-ray diffraction study to reveal a new conformation in which the molecule was stabilized by the $\mathrm{O}-\mathrm{H} \ldots \mathrm{N}$ type intramolecular hydrogen bonding interactions in both moieties. The ATNA was used as a selective electrochemical sensor for the detection of chromium ion $\left(\mathrm{Cr}^{3+}\right)$. A thin film of ATNA was coated on to the flat surface of glassy carbon electrode (GCE) followed by $5 \%$ ethanolic Nafion in order to make the modified GCE (ATNA/Nafion/GCE) as an efficient and sensitive electrochemical sensor. It was found to be very effective and selective against $\mathrm{Cr}^{3+}$ cations in the company of other intrusive heavy metal cations such as $\mathrm{Al}^{3+}, \mathrm{Ce}^{3+}, \mathrm{Co}^{2+}, \mathrm{Cu}^{2+}, \mathrm{Ga}^{3+}, \mathrm{Hg}^{2+}, \mathrm{Mn}^{2+}, \mathrm{Pb}^{2+}$, and $\mathrm{Y}^{3+}$. The detection limit at $3 \mathrm{~S} / \mathrm{N}$ was found to be $0.013 \mathrm{nM}$ for $\mathrm{Cr}^{3+}$ ions within the linear dynamic range (LDR) $(0.1 \mathrm{nM}-10.0 \mathrm{mM})$ of $\mathrm{Cr}^{3+}$ ions with $\mathrm{r}^{2}=0.9579$. Moreover; this work instigates a new methodology for developing the sensitive as well as selective electrochemical toxic cationic sensors in the field of environmental and health care.

Keywords: 1,1'-(-((Disulfanediylbis(2,1-phenylene))bis(azaneylylidene))bis(methaneylylidene))bis (naphthalene-2-ol); homobifunctional tridentate disulfide Schiff base; $\mathrm{Cr}^{3+}$ ions; electrochemical method; glassy carbon electrode; environmental remediation
\end{abstract}

\section{Introduction}

The chemical factories and mining facilities throughout the world discharge overwhelming metal particles and severely affect the environment [1-4]. Hence, accurate quantitative and qualitative detection of such heavy metal ions in an aqueous solution is of prime importance for the protection of the environment. In this regard, the Schiff base structure represents an extraordinary class of ligands because of their facile synthesis from diverse reagents, and the formation of a wide range of complexes with potential applications in different fields such as dye affinity chromatography [5], liquid crystals [6,7], nanocomposite-based polyazommethine [8], medicine [9,10], corrosion inhibitors [11], catalysis [12] and electrochemical sensors [13-15]. Schiff base-derived from 2-aminobenzothiophenol, on the other hand, may have an interesting geometry owing to its propensity for the in situ formed disulfide 
bond [16]. Accordingly, the present work was made to explore the possibility of synthesizing and using of homobifunctional tridentate disulfide Schiff base derived from 2-hydroxy-1-naphthaldehyde and 2-aminothiopheno as a selective cation sensor by an electrochemical approach.

Chromium, among the most well known components, that exists in the earth crust as $\mathrm{Cr}^{3+}$ or $\mathrm{Cr}^{6+}$ cations in combination with other anions as ore e.g., chromite. $\mathrm{Cr}^{3+}$ is a vital component in nutrition, while $\mathrm{Cr}^{6+}$ is profoundly harmful. $\mathrm{Cr}^{3+}$ plays a vital role during metabolism via enzyme activation [17-19]. On the other hand, $\mathrm{Cr}^{3+}$ deficiency in the human body may cause health disorders, including diabetes and cardiovascular diseases. However, a high level of chromium ion in the human body is very harmful as it affects the enzymatic activities and the cellular structures [20]. The maximum permissible level of total chromium, as set by the Environmental Protection Agency (EPA) is $0.1 \mathrm{mg} / \mathrm{mL}[18,21,22]$.

Several analytical techniques, for example, atomic absorption spectrometry (AAS) [23-27], high-performance liquid chromatography (HPLC) coupled with inductive coupled plasma-mass spectrometry (HPLC-ICP-MS), high-performance liquid chromatography coupled with diode array detector (HPLC-DAD), reverse phase ion-pair high-performance liquid chromatography [28-33], ion chromatography inductively coupled plasma-mass spectrometry (IC-ICP-MS) [34,35], mass spectrometry [31], colorimetric and fluorescence spectroscopy [36-39], capillary electrophoresis coupled with UV spectrophotometer [40,41], and chemiluminescence [42] have been reported for the detection of chromium ionic species in addition to some electrochemical approaches such as differential pulse voltammetry [43], adsorptive stripping voltammetry [44], cyclic voltammetry and amperometry [45-48]. Some of the methods that have been stipulated above are very expensive and complicated for the detection of chromium. If some are fortunately cost effective, then they are not effectual with respect to the detection limit, and some exist with other old classical electrochemical methods for its detection.

Therefore, it is of great interest to develop a new, trustworthy, efficient, selective and cost-effective (cheap) techniques for the detection of chromium ion $\left(\mathrm{Cr}^{3+}\right)$, qualitatively, and quantitatively. In this study, an electrochemical approach, current-potential (I-V) technique, based on newly modified glassy carbon electrode, 1,1'-(-((disulfanediylbis(2,1-phenylene))bis(azaneylylidene))bis(methaneylylidene)) bis(naphthalene-2-ol) (ATNA)/Nafion/GCE, as an agile and selective electrochemical sensor, was applied for the first time for the practical determination of $\mathrm{Cr}^{3+}$ ions in an aqueous media (phosphate buffer saline (PBS)). The modified GCE (ATNA/Nafion/GCE) was fabricated by coating the newly synthesized, homobifunctional tridentate ATNA Schiff base, which acts as a chelating agent onto its flat surface followed by $5 \%$ ethanolic Nafion as conducting the polymer binder. It furnishes the very sensitive transduction at the interface of liquid/surface electrode in phosphate buffer saline (PBS) $(0.1 \mathrm{M}$ at $7.0 \mathrm{pH})$. To the best of our knowledge, this is the first cationic electrochemical sensing application based on the current-potential technique by using a newly modified GCE as a working electrode for sensing the $\mathrm{Cr}^{3+}$ ions within a very short response time of 10 to $20 \mathrm{~s}$, qualitatively and quantitatively, in an aqueous neutral solution.

\section{Experimental}

\subsection{Materials and Methods}

All solvents and reagents were purchased from Sigma-Aldrich Company and used as received. Then, $1 \mathrm{H}$ and $13 \mathrm{C}$ NMR spectra were recorded in $\mathrm{CDCl}_{3}$ solutions on a Bruker Avance $850 \mathrm{MHz}$ spectrometer. The attenuated total reflectance-Fourier transform infrared (ATR-FTIR) spectrum was performed on a PerkinElmer spectrum 100 FT-IR spectrometer. The melting point was determined in an open capillary tube in a Stuart Scientific melting point apparatus (SMP3) and was uncorrected. De-ionized water was used for the making the stock as well as the chemical solutions of different concentration in whole study. 
The current-potential ( $I-V)$ technique was measured using the Keithley 6517A, Electrometer (USA), as a constant voltage source. The detection of chromium cation $\left(\mathrm{Cr}^{3+}\right)$ in the phosphate buffer medium at applied potential ranging from 0 to $+1.5 \mathrm{~V}$ was made using a newly designed ATNA/Nafion/GCE and $\mathrm{Pt}$-wire as the working electrode and counter electrode, respectively, by measuring the I-V responses in two electrode systems (lab-made electrochemical cell). Moreover, this novel $(I-V)$ method follows the Ohms law that measures the current against the potential applied.

\subsection{Synthesis of $1,1^{\prime}-(-(($ disulfanediylbis(2,1-phenylene $))$ bis(azaneylylidene $\left.)\right)$ bis(methaneylylidene)) bis(naphthalen-2-ol) (ATNA)}

A solution of 2-aminothiophenol $(0.88 \mathrm{~g}, 7.0 \mathrm{mmol})$ and 2-hydroxy-1-naphthaldehyde $(1.21 \mathrm{~g}$, $7.0 \mathrm{mmol}$ ) in $50.0 \mathrm{ml}$ absolute ethanol was refluxed with stirring overnight, and then left to cool. The brownish-orange precipitate was filtered and then washed with ethanol to give $1.8 \mathrm{~g}, 92.5 \%$ yield. The product was re-crystallized slowly from toluene to obtain the single crystal. Mp: $221-220{ }^{\circ} \mathrm{C}$. ${ }^{1} \mathrm{H} \mathrm{NMR}\left(\mathrm{CDCl}_{3}, 850 \mathrm{MHz}, \delta=\mathrm{ppm}\right): 7.20(6 \mathrm{H}, \mathrm{m}, \mathrm{Ar}-\mathrm{H}), 7.27(2 \mathrm{H}, \mathrm{d}, \mathrm{J}=8.5 \mathrm{~Hz}, \mathrm{ArH}), 7.40(2 \mathrm{H}, \mathrm{t}$, $\mathrm{J}=7.65-8.5 \mathrm{~Hz}, \mathrm{Ar}-\mathrm{H}), 7.56$ (2H, t, J =7.65-8.5 Hz, Ar-H), $7.73(2 \mathrm{H}, \mathrm{d}, \mathrm{J}=7.65 \mathrm{~Hz}, \mathrm{Ar}-\mathrm{H}), 7.80$ (2H, d, $\mathrm{J}=7.65 \mathrm{~Hz}, \mathrm{Ar}-\mathrm{H}), 7.89(2 \mathrm{H}, \mathrm{d}, \mathrm{J}=8.5 \mathrm{~Hz}, \mathrm{Ar}-\mathrm{H}), 8.19(2 \mathrm{H}, \mathrm{d}, \mathrm{J}=8.5 \mathrm{~Hz}, \mathrm{Ar}-\mathrm{H}), 9.45(2 \mathrm{H}, \mathrm{s}, 2 \mathrm{~N}=\mathrm{CH})$, $14.95(2 \mathrm{H}, \mathrm{s}, 2 \mathrm{OH}),{ }^{13} \mathrm{C} \mathrm{NMR}\left(\mathrm{CDCl}_{3}, 213 \mathrm{MHz}, \delta=\mathrm{ppm}\right): 109.56,118.08,119.31,120.60,123.69,127.30$, 127.76, 128.06,128.36, 129.07, 129.39, 130.98, 132.99, 135.98, 146.45, 157.55, 157.61; FTIR (ATR, $\left.\mathrm{cm}^{-1}\right)$ : $3061,3001,2972,1622,1602,1586,1551,1461,1217,819,744,449$.

\subsection{X-ray Crystallography of ATNA}

The sample compound was crystalized for single crystal diffraction studies. The crystals were taken out from the crystallization flask and screened out under the microscope. The suitable crystal was selected and pasted over the glass tip using commercial glue. The glass tip was immersed into the wax supported by a hollow copper rod and a magnetic base. This holder was mounted on an Agilent SuperNova (Dual source) Agilent Technologies Diffractometer, equipped with graphite-monochromatic $\mathrm{Cu} / \mathrm{Mo} \mathrm{K} \alpha$ radiation for data collection. The data collection was accomplished using CrysAlisPro software [49] at $296 \mathrm{~K}$ under the $\mathrm{Cu} \mathrm{K} \alpha$ radiation. The structure solution was performed using SHELXS-97 [50] and refined by full-matrix least-squares methods on $F^{2}$ using SHELXL-97 [50], in-built with WinGX [51]. All non-hydrogen atoms were refined anisotropically by full-matrix least squares methods [50]. Figures were drawn using PLATON [52] and ORTEP-3 [53].

All the aromatic hydrogen atoms were positioned geometrically and treated as riding atoms with $\mathrm{C}-\mathrm{H}=0.93 \AA$ and $\mathrm{Uiso}(\mathrm{H})=1.2 \mathrm{Ueq}(\mathrm{C})$ carbon atoms. The $\mathrm{O}-\mathrm{H}=0.82 \AA$ and $\mathrm{O}-\mathrm{H}=0.93(6) \AA$, hydrogen atom was also positioned geometrically and treated as a riding atom with $\mathrm{Uiso}(\mathrm{H})=1.5 \mathrm{Ueq}(\mathrm{O})$, respectively. The crystallographic information file (CIF) of compound I was submitted to the Cambridge Crystallographic Data Centre (CCDC). The CCDC number (1953254) obtained against it is mentioned in Table 1. These data can be obtained free of charge at www.ccdc.cam.ac.uk/conts/retrieving.html or from the Cambridge Crystallographic Data Centre, 12 Union Road, Cambridge CB2 1EZ, UK. 
Table 1. Data and structure refinement for ATNA.

\begin{tabular}{|c|c|}
\hline CCDC Code (Cambridge Crystallographic Data Centre) & 1953254 \\
\hline Empirical formula & $\mathrm{C}_{34} \mathrm{H}_{24} \mathrm{~N}_{2} \mathrm{O}_{2} \mathrm{~S}_{2}$ \\
\hline Formula weight & 556.67 \\
\hline Temperature/K & $296(2)$ \\
\hline Crystal system & triclinic \\
\hline Space group & $\mathrm{P}-1$ \\
\hline $\mathrm{a} / \AA ̊ \AA$ & $8.6843(5)$ \\
\hline $\mathrm{b} / \AA$ & $11.8282(6)$ \\
\hline$c / \AA$ & $13.5159(9)$ \\
\hline$\alpha /^{\circ}$ & $78.828(5)$ \\
\hline$\beta /^{\circ}$ & $82.291(5)$ \\
\hline$\gamma /^{\circ}$ & $86.223(4)$ \\
\hline Volume $/ \AA^{3}$ & $1348.59(14)$ \\
\hline Z & 2 \\
\hline$\rho_{\text {calc }} \mathrm{g} / \mathrm{cm}^{3}$ & 1.371 \\
\hline$\mu / \mathrm{mm}^{-1}$ & 0.233 \\
\hline $\mathrm{F}(000)$ & 580.0 \\
\hline Crystal size $/ \mathrm{mm}^{3}$ & $0.22 \times 0.17 \times 0.12$ \\
\hline Radiation & $\operatorname{MoK} \alpha(\lambda=0.71073)$ \\
\hline $2 \theta$ range for data collection $/^{\circ}$ & 5.942 to 58.364 \\
\hline Index ranges & $-11 \leq \mathrm{h} \leq 7,-15 \leq \mathrm{k} \leq 15,-17 \leq 1 \leq 18$ \\
\hline Reflections collected & 12,053 \\
\hline Independent reflections & $6334\left(R_{\text {int }}=0.0338, R_{\text {sigma }}=0.0553\right)$ \\
\hline Data/restraints/parameters & $6334 / 0 / 361$ \\
\hline Goodness-of-fit on $\mathrm{F}^{2}$ & 1.031 \\
\hline Final $R$ indexes indexes $(I>=2 \sigma(I))$ & $\mathrm{R}_{1}=0.0538, \mathrm{w} \mathrm{R}_{2}=0.1211$ \\
\hline Final R indexes (all data) & $\mathrm{R}_{1}=0.1039, \mathrm{wR}_{2}=0.1544$ \\
\hline Largest diff. peak/hole / e $\AA^{-3}$ & $0.23 /-0.27$ \\
\hline
\end{tabular}

\subsection{Fabrication of ATNA/Nafion/GCE as a Selective $\mathrm{Cr}^{3+}$ Electrochemical Sensor}

For the fabrication of ATNA/Nafion/GCE as a selective $\mathrm{Cr}^{3+}$ electrochemical sensor, a simple and reliable approach was practiced. The geometrical dimension of the GCEs that were used for the fabrication of GCE as a selective $\mathrm{Cr}^{3+}$ electrochemical sensor, was $12 \mathrm{~cm}$ in length with a copper rod and $0.0316 \mathrm{~cm}^{2}$ in surface area. Before the fabrication of the GCE, it was washed by using a very simple protocol. First, the GCE was dipped in acetone for $10 \mathrm{~min}$. After that, it was washed thoroughly with deionized water followed by ethanol-soaked cotton buds and dried in an oven for $15 \mathrm{~min}$ at $80^{\circ} \mathrm{C}$. After proper washing, a slurry of approximately $1.5 \mathrm{mg}$ of synthesized ATNA was made with ethanol, and then applied onto the flat surface of GCE with one to two drops of $5 \%$ ethanolic Nafion as an adhesive conducting binder. Then, the freshly fabricated electrode was dried at $35^{\circ} \mathrm{C}$ for $45 \mathrm{~min}$ in an oven in order to get the ATNA/Nafion/GCE as a selective and sensitive $\mathrm{Cr}^{3+}$ electrochemical sensor, Scheme 1. This newly designed ATNA/Nafion/GCE as a selective $\mathrm{Cr}^{3+}$ sensor was therefore used as a working electrode to measure the I-V (current-potential) response in a phosphate buffer saline (PBS) medium of $\mathrm{pH}=7$, in the presence or absence of $\mathrm{Cr}^{3+}$ ions, in a lab-made electrochemical 
cell (beaker) in which Pt-wire was used as a counter electrode. The (PBS) medium of $\mathrm{pH}=7$ was made by mixing the equimolar solution of disodium phosphate $(0.2 \mathrm{M}, 39.0 \mathrm{~mL})$ with monosodium phosphate $(0.2 \mathrm{M}, 61.0 \mathrm{~mL})$ in a $100 \mathrm{~mL}$ measuring flask. In the whole study, $\mathrm{Cr}^{3+}$ was used as a target analyte in the presence of other interference cations. The stock solution of $\mathrm{Cr}^{3+}$ was used to get the different concentration range of $\mathrm{Cr}^{3+}$ (full concentration range: $0.01 \mathrm{nM} \sim 0.1 \mathrm{M}$ ) in deionized water by dilution method. Similarly, the amount $(10.0 \mathrm{~mL})$ of $(0.2 \mathrm{M})$ PBS of $\mathrm{pH}=7$ was kept constant in every trial or throughout the whole study in a lab-made electrochemical cell in order to measure the $\mathrm{I}-\mathrm{V}$ response, in the presence as well as in the absence of the target analyte. Correspondingly, different analytical parameters such as sensitivity, full concentration range as well as linear dynamic range (LDR), regression coefficient $\mathrm{r}^{2}$, the limit of detection at S/N 3 (LOD) and limit of quantification (LOQ), for $\mathrm{Cr}^{3+}$ were also measured from the slope of the calibration plot (current versus concentration) by using the newly designed ATNA/Nafion/GCE as a selective $\mathrm{Cr}^{3+}$ sensor.

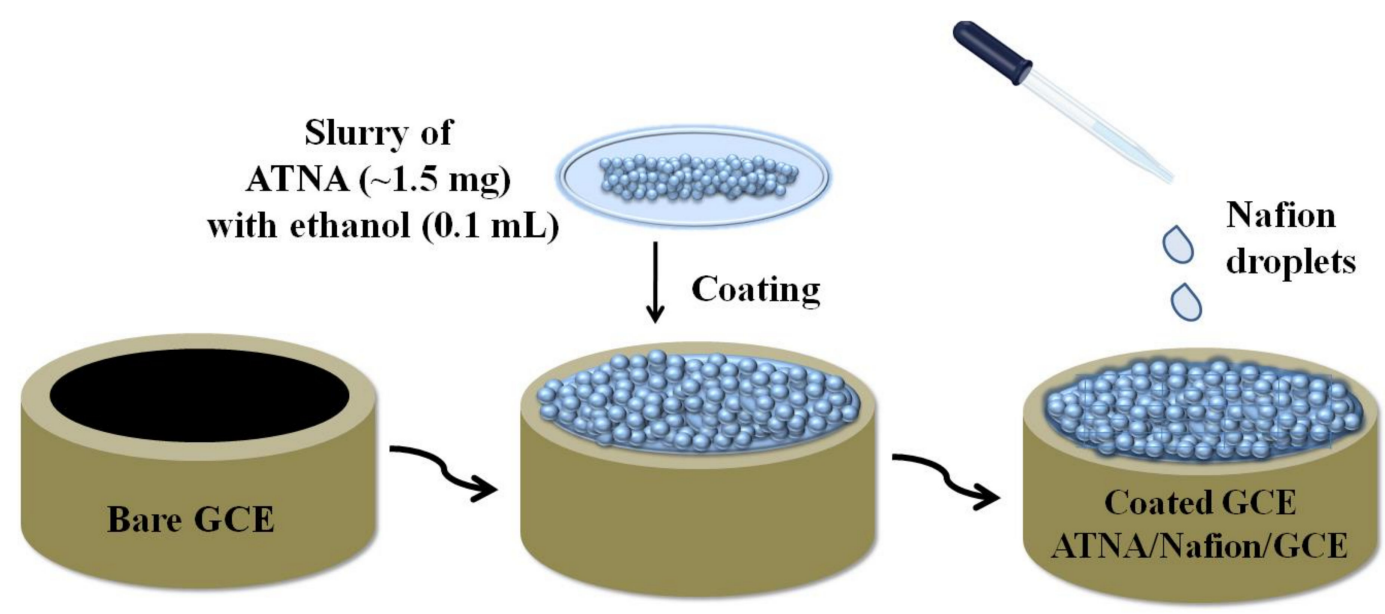

Scheme 1. Fabrication of glassy carbon electrode GCE modified by, 1'-(-((disulfanediylbis (2,1-phenylene))bis(azaneylylidene))bis(methaneylylidene))bis(naphthalene-2-ol) (ATNA) with the conducting binder, $5 \%$ Nafion.

\section{Results and Discussion}

\subsection{Synthesis}

It was envisioned that having disulfide-containing homobifunctional Schiff base as a tridentate ligand would make a stable film on a glassy carbon electrode for the electrochemical detection of toxic metal ions from aqueous solution. Little information on ATNA with a different single-crystal structure from the present one has been reported [16]. The synthesis of ATNA was easily obtained in one step in excellent yield by refluxing the 1:1 molar ratio of 2-aminothiphenol and 2-hydroxynaphthaldehyde in absolute ethanol for $19 \mathrm{~h}$ (Scheme $2 \mathrm{a}$ ). The single crystal of the product was obtained by recrystallization from toluene. It is suggested that the formation of the ATNA ligand proceeds via condensation to get the corresponding Schiff base, which further undergoes the in situ oxidation of thiol to the corresponding disulfide by virtue of the dissolved oxygen. The oxidation proceeds via a thyil radical in a one-electron transfer process that dimerizes to give the disulfide (Scheme 2b) [54].

NMR (proton and carbon, see Supplementary Files S1-S6, Figures S1 and S2), ATR-FTIR, and single-crystal measurements were made to confirm the chemical structure of ATNA. The ATR-FTIR spectrum of ATNA reveals the characteristic bands of aromatic Schiff base imine group $(\mathrm{CH}=\mathrm{N})$ at $1622 \mathrm{~cm}^{-1}$. It is noteworthy to observe, as shown in Figure 1, the absence of the vibration peak of the $\mathrm{OH}$ group, but instead the appearance of weak bands at 2972,3001, $3061 \mathrm{~cm}^{-1}$ due to the stretching vibrations of $\mathrm{C}-\mathrm{H}$ of imine and phenyl groups. The absence of $\mathrm{OH}$ vibration is attributed to the existence of the intramolecular hydrogen bond between $\mathrm{OH}$ and $\mathrm{CH}=\mathrm{N}$ and $\mathrm{S}-\mathrm{S}$ (Scheme 3), as it will be emphasized further below in ${ }^{1} \mathrm{H}$ NMR and single-crystal data. This IR attribution is in accordance 
with a similar Schiff base reported earlier $[14,15,55]$. The stretching vibration frequency of aromatic disulfide (S-S) appears at $449 \mathrm{~cm}^{-1}$ as similarly reported [56]. The sharp band appearing at $744 \mathrm{~cm}^{-1}$ may correspond to disulfides (C-S stretch) and 1,2-disubstituted aromatic. The band at $819 \mathrm{~cm}^{-1}$ corresponds to the aromatic $\mathrm{C}-\mathrm{H}$ bending vibration [56]. Moreover, the stretching vibrations due to $\mathrm{C}=\mathrm{N}$ - appear at 1602 and $1586 \mathrm{~cm}^{-1}$. On the other hand, bands due to $\mathrm{C}=\mathrm{C}$ aromatic and $\mathrm{C}-0$ of phenolic groups appear at 1551,1461, and $1217 \mathrm{~cm}^{-1}$, respectively.

(a)<smiles>O=Cc1c(O)ccc2ccccc12</smiles>

1

Absolute ethanol

Reflux for $19 \mathrm{~h}$<smiles>Nc1ccccc1S</smiles>

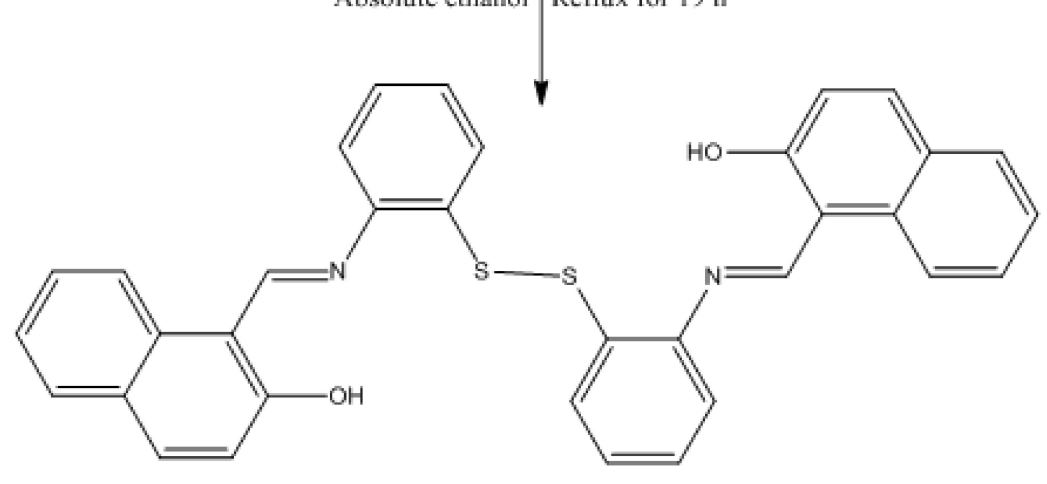

ATNA $_{A}$
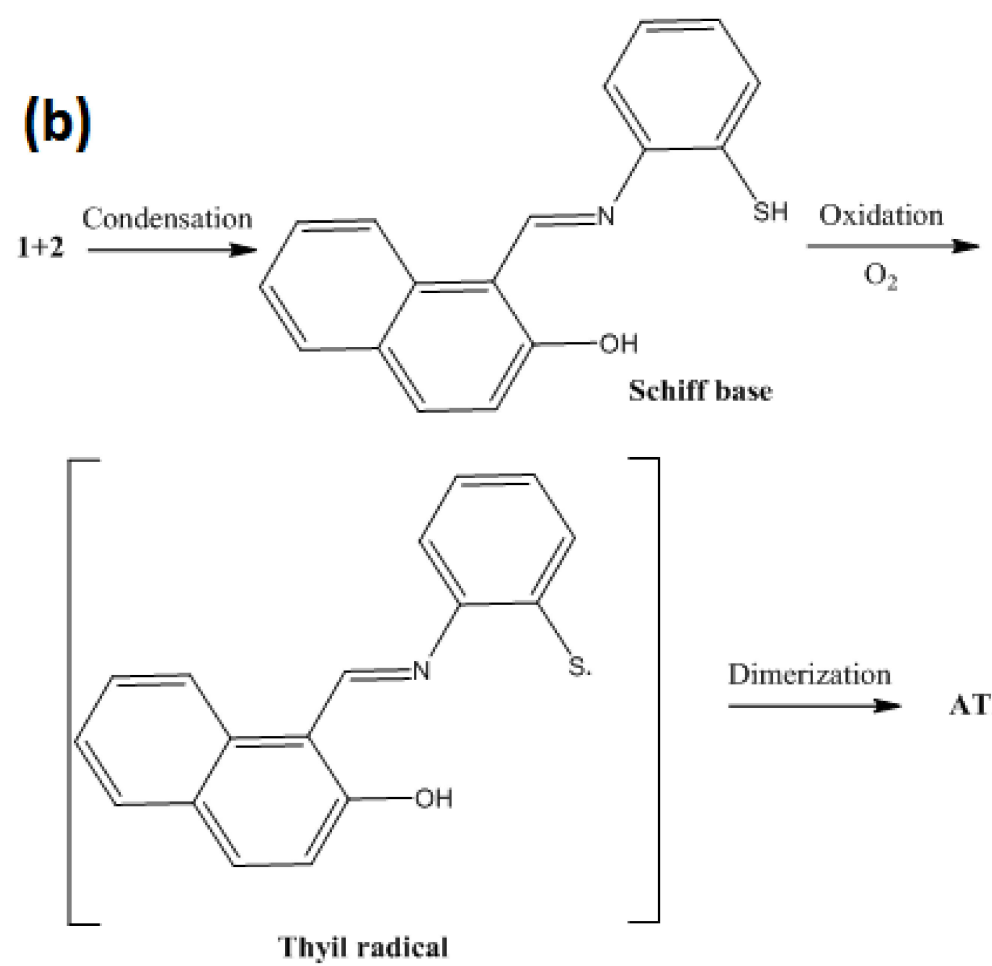

Dimerization

ATNA

Scheme 2. (a) Synthesis of ATNA. (b) Suggested mechanism for the formation of ATNA. 


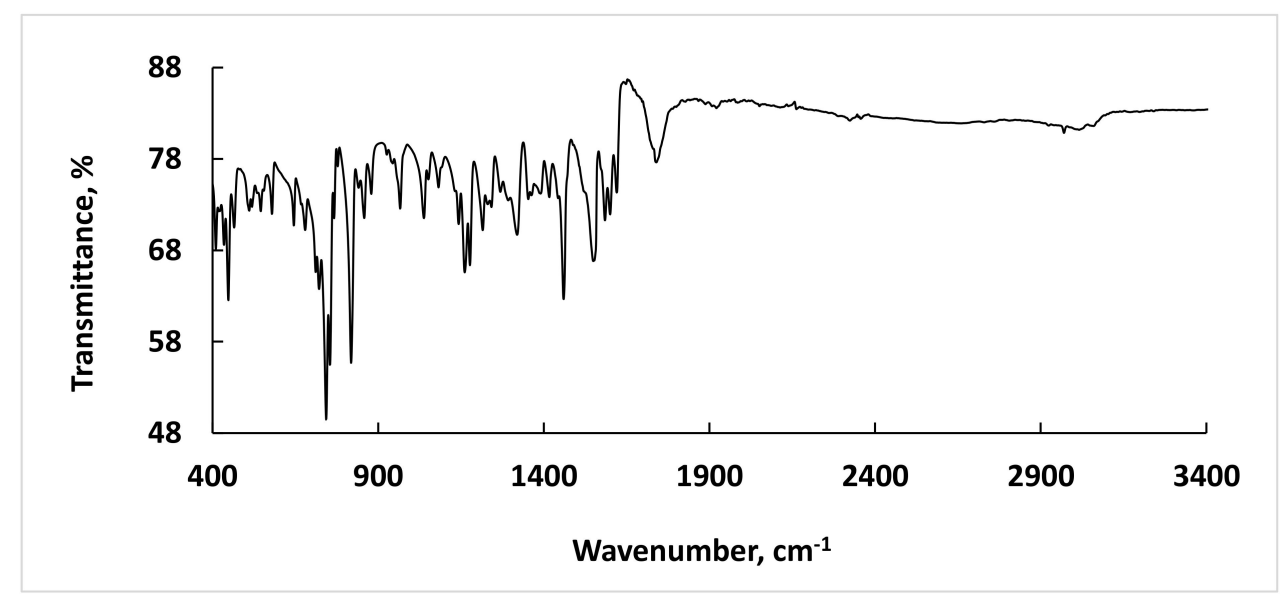

Figure 1. Attenuated total reflectance-Fourier transform infrared (ATR-FTIR) of the ATNA molecule.

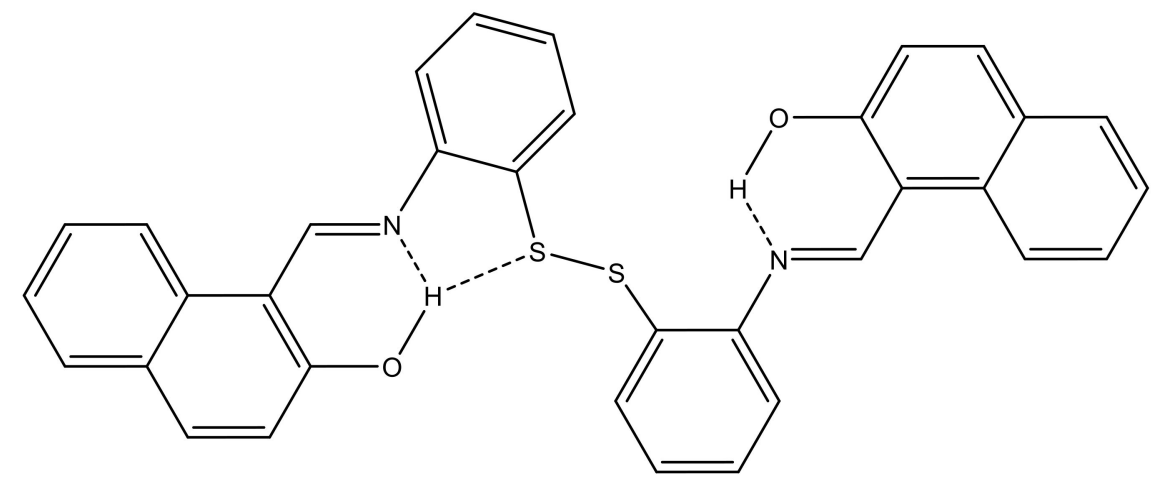

Scheme 3. Intramolecular hydrogen bonds in ATNA.

The proton NMR data reveals the imine protons as a singlet at $9.45 \mathrm{ppm}$ and $\mathrm{OH}$ groups as singlet downfield at $14.95 \mathrm{ppm}$ because of the existence of intramolecular hydrogen bonds that increase the acidity of $\mathrm{OH}$ groups. Furthermore, the formation of such intramolecular hydrogen bonds near aromatic moieties may deshield the $\mathrm{OH}$ groups by magnetic anisotropic effect [14,15]. Other protons with their coupling constants are nicely correlated, and the total number of protons are presented per the chemical structure of ATNA. In addition, ${ }^{13} \mathrm{C}$ NMR reveals all the carbons present in ATNA and the characteristic peak of imine carbon appears at $165.49 \mathrm{ppm}$.

\subsection{Crystal Description}

The molecule 1,1'-(-((disulfanediylbis(2,1-phenylene))bis(azaneylylidene))bis(methaneylylidene)) bis(naphthalen-2-ol) is basically a dimer of 1-[(2-Mercapto-phenylimino)-methyl]-naphthalen-2-ol which are connected through a sulphur atom. The single crystal diffractions were carried out to support our spectroscopic data, the confirmation of the synthesized product and to attract the readers for further any applications. The S-S bond distance is 2.0234 (10) $\AA$, which is in accordance with already published related structures [57]. The Schiff base parts (A and B) of the molecule around the S-S bonds have a different geometry, due to which there is no center of symmetry or point symmetry in it, Figure 2. The crystallographic parameters are given in Table 1, while selected bond lengths and bond angles are provided in Tables S1 and S2. In part A (C1-C17), the benzene ring and naphthalene rings were twisted at a dihedral angle of $2.396(1)^{\circ}$ while the in part $\mathrm{B}(\mathrm{C} 18-\mathrm{C} 34)$, these rings were twisted at a dihedral angle of $28.396(1)^{\circ}$. The conformation around the imine bond $(\mathrm{C}=\mathrm{N})$ in both parts is trans, favoring the molecule to stay in the most stable form. The molecule was stabilized by the $\mathrm{O}-\mathrm{H} \ldots \mathrm{N}$ type intramolecular hydrogen bonding interactions (Table 2). These interactions produced six-membered ring motifs $[S(6)]$ with the root mean square deviation values of $0.0250(2) \AA$ 
and $0.0190 \AA$ for the rings $(\mathrm{C} 1 / \mathrm{C} 2 / \mathrm{C} 11 / \mathrm{N} 1 / \mathrm{H} 1 \mathrm{O} / \mathrm{O} 1)$ and $(\mathrm{C} 24 / \mathrm{C} 25 / \mathrm{C} 26 / \mathrm{N} 2 / \mathrm{H} 2 \mathrm{O} / \mathrm{O} 2)$. The former ring motif is turned at dihedral angles of 79.72(7) with respect to the benzene ring (C12-C17) while the later ring is twisted by 4.071(15) with the aromatic ring (C18-C23) Figure 3. The O2-H2O ... N2 and $\mathrm{O} 2-\mathrm{H} 2 \mathrm{O}$... S2 interactions produced two ring motifs (Figure 3 and Figure S3), (i) a nine-membered ring motif (C18/C19/N2/C24/C25/C26/O2/H2O/S2) which can be represented mathematically as $S(9)$ [58], (ii) a five-membered ring motif where $\mathrm{O} 2$ acts as donor atom via $\mathrm{H} 2 \mathrm{O}$ to $\mathrm{N} 2$ and $\mathrm{S} 2$ so this can be represented as $S_{1}{ }^{2}(5)$. From Figure S4, we can observe that planes of aromatic benzene and naphthalene are parallel to each other give rise to the $\pi-\pi$ interactions among them to afford the extra stability to the crystal structure of the subjected compound.

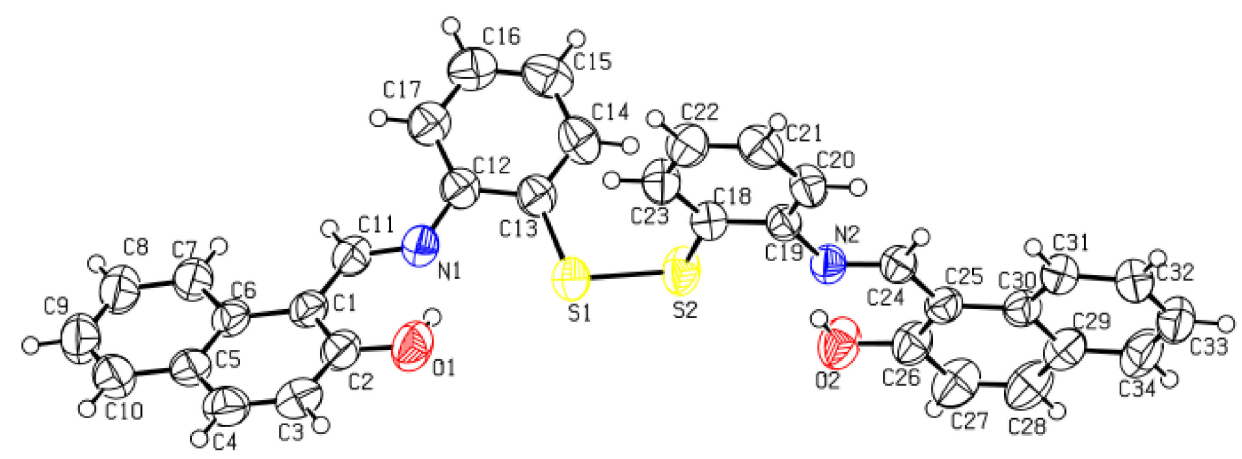

Figure 2. Plot for ATNA with 50\% probability of thermal ellipsoids.

Table 2. Hydrogen bonds for ATNA.

\begin{tabular}{ccccccc}
\hline $\mathbf{D}$ & $\mathbf{H}$ & $\mathbf{A}$ & $\mathbf{d}(\mathbf{D}-\mathbf{H}) / \AA$ & $\mathbf{d}(\mathbf{H}-\mathbf{A}) / \AA$ & $\mathbf{d}(\mathbf{D}-\mathbf{A}) / \AA$ & $\mathbf{D}-\mathbf{H}-\mathbf{A} /{ }^{\circ}$ \\
\hline $\mathrm{O} 1$ & $\mathrm{H} 1 \mathrm{O}$ & $\mathrm{N} 1$ & 0.82 & 1.85 & $2.575(3)$ & 146.8 \\
\hline $\mathrm{O} 2$ & $\mathrm{H} 2 \mathrm{O}$ & $\mathrm{N} 2$ & 0.82 & 1.85 & $2.574(3)$ & 147.4 \\
\hline $\mathrm{O} 2$ & $\mathrm{H} 2 \mathrm{O}$ & $\mathrm{S} 2$ & 0.82 & 2.74 & $3.410(2)$ & 139.7 \\
\hline
\end{tabular}

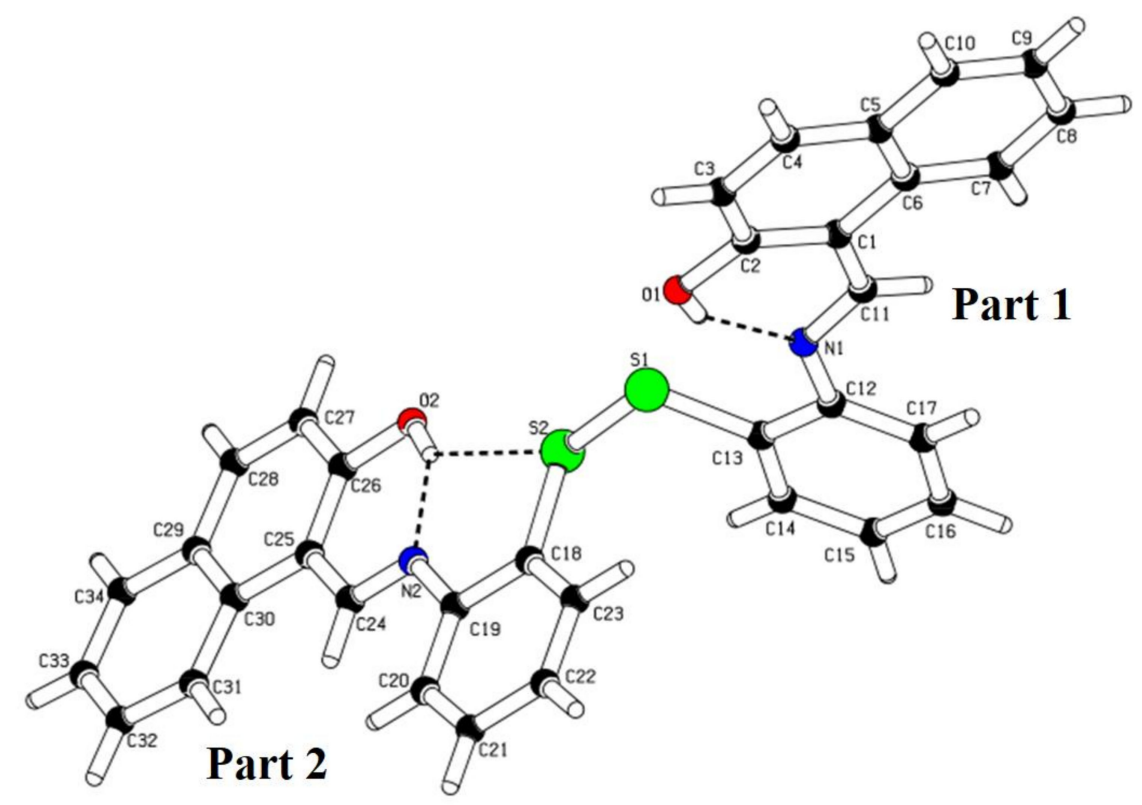

Figure 3. A labeled diagram showing the intramolecular interactions and the formation of different ring motifs. 


\subsection{Application: Detection of $\mathrm{Cr}^{3+}$ Cation with ATNA Modified GCE}

The most inspiring application of the homobifunctional tridentate ATNA Schiff base is the selective electrochemical sensing of Chromium (III) cations in an aqueous system in the presence of other interfering toxic/heavy metal cations. An electrochemical current-potential (I-V) approach based on a newly modified GCE (ATNA/Nafion/GCE) was applied for the first time for the sensing of $\mathrm{Cr}^{3+}$ ions in a lab-made electrochemical cell (two-electrode system accommodating a working electrode and a counter electrode in an aqueous solution). Moreover, the fabrication of the newly modified GCE has already been discussed in the experimental section of this study. Therefore, the fabrication of ATNA/Nafion/GCE for the probe of $\mathrm{Cr}^{3+}$ ions in an aqueous solution by means of the (I-V) technique is the new approach. It is highly efficient as well as a selective electrochemical sensor against the $\mathrm{Cr}^{3+}$. Moreover, no other reports have been cited in the literature by using this newly designed ATNA/Nafion/GCE as a selective $\mathrm{Cr}^{3+}$ electrochemical sensor. A remarkable variation in the current response was observed against the potential applied $(0$ to $+1.5 \mathrm{~V})$ in response to the absorbed analyte, $\mathrm{Cr}^{3+}$ onto the surface of the modified GCE. During the whole study, the concentration of our target analyte, as well as other heavy metal cations, were taken as $25.0 \mu \mathrm{L}$ of $0.1 \mu \mathrm{M}$ through a micropipette. After the fertile change in the current response, analytical parameters such as LDR, LOD, and LOQ were calculated from the calibration curve so as to optimize the ATNA/Nafion/GCE sensor as a sensitive and selective electrochemical sensor for the detection of $\mathrm{Cr}^{3+}$, qualitatively and quantitatively.

At first, a change in the current response of the modified GCE (ATNA/Nafion/GCE) against the potential applied was recorded and evaluated with bare GCE. It was observed, that the ATNA/Nafion/GCE shows the high current response in contrast to a non-modified GCE due to the sensitive and excellent communication of the electron transduction in a PBS medium at the liquid/surface electrode interface, Figure 4a. After that, a selectivity study was conducted, and it was found to be very selective against the $\mathrm{Cr}^{3+}$ ions in the presence of other heavy metal cations such as $\mathrm{Al}^{3+}, \mathrm{Ce}^{3+}, \mathrm{Co}^{2+}, \mathrm{Cu}^{2+}, \mathrm{Ga}^{3+}, \mathrm{Hg}^{2+}, \mathrm{Mn}^{2+}, \mathrm{Pb}^{2+}$, and $\mathrm{Y}^{3+}$, Figure $4 \mathrm{~b}$. After the confirmation of selectivity of a newly modified GCE (ATNA/Nafion/GCE) against the $\mathrm{Cr}^{3+}$ ions, then a change in the current response of ATNA/Nafion/GCE against the potential applied was also checked in the presence and absence of a $\mathrm{Cr}^{3+}$ ion in order to check its affinity for $\mathrm{Cr}^{3+}$ ions. It was noticed that newly modified GCE gives a high response in the presence of $\mathrm{Cr}^{3+}$ ions as compared to its response in the absence of $\mathrm{Cr}^{3+}$ ions in PBS of $\mathrm{pH}=7$, Figure $4 \mathrm{a}$.
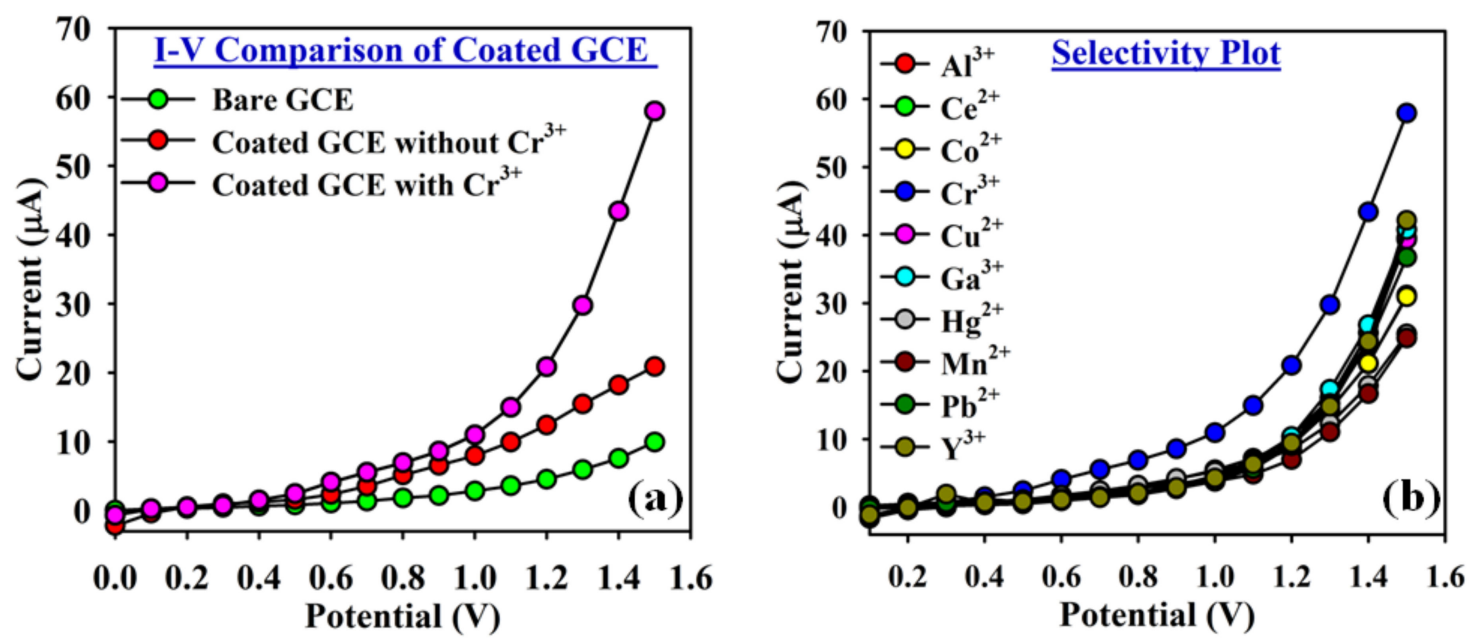

Figure 4. Selectivity study: (a) current potential (I-V) response of the bare and coated GCE (ATNA/Nafion/GCE) in the presence and absence of $\mathrm{Cr}^{3+}$ ions as our target analyte at $0.1 \mu \mathrm{M}$, $25.0 \mu \mathrm{L}$; (b) $\mathrm{I}-V$ response with various analytes (showing affinity with $\mathrm{Cr}^{3+}$ ), concentration of each analyte was taken at $(0.1 \mu \mathrm{M}, 25.0 \mu \mathrm{L})$. 
After the selectivity, the interference study was conducted by using a statistical approach. The interference effect, in the presence of $\mathrm{Cr}^{3+}$ ions and of other heavy metal cations $\left(\mathrm{Al}^{3+}, \mathrm{Ce}^{3+}, \mathrm{Co}^{2+}\right.$, $\mathrm{Cu}^{2+}, \mathrm{Ga}^{3+}, \mathrm{Hg}^{2+}, \mathrm{Mn}^{2+}, \mathrm{Pb}^{2+}$, and $\mathrm{Y}^{3+}$ ) on ATNA/Nafion/GCE was checked by measuring the I-V response at $+1.1 \mathrm{~V}$ at STP and shown in Figure 5 and Table 3. The concentration of each analyte was taken at $(0.1 \mu \mathrm{M}, 25 \mu \mathrm{L})$ in PBS medium of $\mathrm{pH}=7$. By this experiment, it was concluded that the modified GCE (ATNA/Nafion/GCE) is very selective for the $\mathrm{Cr}^{3+}$ ions, and it does not have any impressive impact towards the other above stipulated interfering heavy metal cations. Therefore, Figure $4 \mathrm{~b}$ (selectivity) as well as Figure 5 (interference study) show that our synthesized compound has more affinity with $\mathrm{Cr}^{3+}$. Moreover, our synthesized ATNA also shows very little affinity with other heavy metal ions but these metal ions showed the similar current response against the potential applied up to $+1.0 \mathrm{~V}$ but still cannot be distinguished with each other.

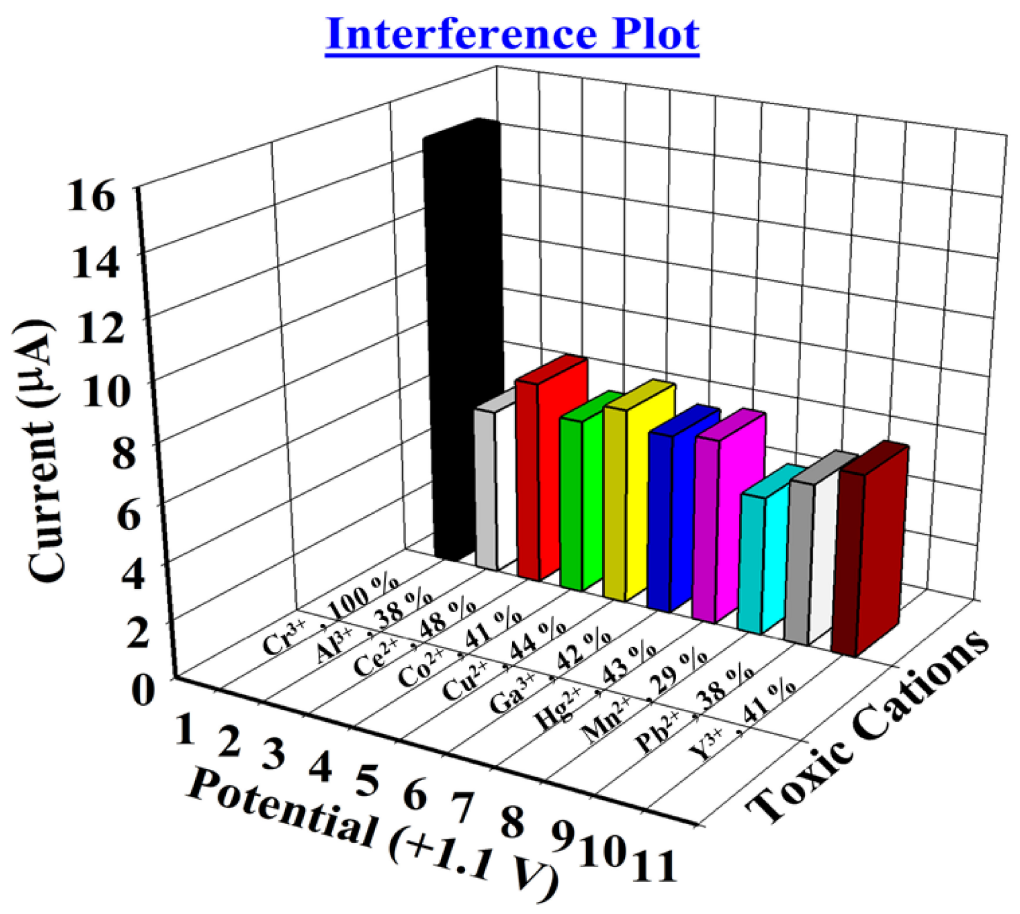

Figure 5. Interference study: comparison of the I-V responses of the interfering heavy metal cations at potential $(+1.1 \mathrm{~V})$. Analytes concentrations were taken as $25 \mu \mathrm{L}$ of $0.1 \mu \mathrm{M}$, delay time one second.

Table 3. Interference effect of the various cations with ATNA/Nafion/GCE.

\begin{tabular}{|c|c|c|c|c|c|c|c|}
\hline \multirow{2}{*}{$\begin{array}{l}\text { Metal } \\
\text { Ions }\end{array}$} & \multicolumn{4}{|c|}{ Observed Current $(\mu \mathrm{A})$} & \multirow{2}{*}{$\begin{array}{c}\text { Interference } \\
\text { Effect (\%) }\end{array}$} & \multirow{2}{*}{${ }^{*} \mathrm{SD}(\mathrm{n}=3)$} & \multirow{2}{*}{$\begin{array}{c}{ }^{\#} \text { RSD (\%) } \\
(n=3)\end{array}$} \\
\hline & R1 & R2 & R3 & Average & & & \\
\hline $\mathrm{Cr}^{3+}$ & 14.9618 & 14.8241 & 15.1423 & 14.9760 & 100 & 0.1595 & 1.07 \\
\hline $\mathrm{Al}^{3+}$ & 5.2456 & 6.1323 & 5.8625 & 5.7468 & 38 & 0.4545 & 7.91 \\
\hline $\mathrm{Ce}^{2+}$ & 7.1919 & 7.2031 & 7.1879 & 7.1943 & 48 & 0.0078 & 0.11 \\
\hline $\mathrm{Co}^{2+}$ & 6.1792 & 6.2955 & 6.0095 & 6.1614 & 41 & 0.1438 & 2.33 \\
\hline $\mathrm{Cu}^{2+}$ & 6.5441 & 6.6192 & 6.8994 & 6.6875 & 44 & 0.1872 & 2.80 \\
\hline $\mathrm{Ga}^{3+}$ & 6.3739 & 6.2084 & 6.3215 & 6.3012 & 42 & 0.0845 & 1.34 \\
\hline $\mathrm{Hg}^{2+}$ & 6.5512 & 6.4989 & 6.3003 & 6.4501 & 43 & 0.1323 & 2.05 \\
\hline $\mathrm{Mn}^{2+}$ & 4.0958 & 4.3853 & 4.8554 & 4.4455 & 29 & 0.3833 & 8.62 \\
\hline $\mathrm{Pb}^{2+}$ & 5.9285 & 5.7969 & 5.6714 & 5.7989 & 38 & 0.1285 & 2.22 \\
\hline $\mathrm{Y}^{3+}$ & 5.8275 & 6.2791 & 6.3461 & 6.1509 & 41 & 0.2820 & 4.59 \\
\hline
\end{tabular}

Interference effect of $\mathrm{Cr}^{3+}$ is considered to be $100 \%$; $\mathrm{R}$ = reading; ${ }^{*} \mathrm{SD}=$ standard deviation; and ${ }^{\#} \mathrm{RSD}=$ relative standard deviation. 
A control experiment was also performed to check the effect of Nafion coating onto GCE. For this purpose, it was compared the electrochemical investigation with only GCE and Nafion/GCE were presented in Figure 6a. Here, it was observed that in presence of Nafion coating, the sensor signal did not have any significant changes compared to only the bare GCE in identical conditions. The Nafion/GCE electrode exhibited an almost similar current like bare GCE, and no significant changes in the current were observed. In this study, Nafion is used as a conducting coating binders to stick the ATNA materials onto the GCE for electrochemical analysis. Additionally, we performed a control experiment with both tri- and hexa-valent chromium as well as without analyte by ATNA/Nafion/GCE sensor probe and included the results in Figure $6 \mathrm{~b}$. Here, $\mathrm{Cr}(\mathrm{VI})$ shows less electrochemical response compared to the $\mathrm{Cr}^{3+}$ in identical conditions. Therefore, in this investigation, it was selected as the only $\mathrm{Cr}^{3+}$ sensor probe development based on ATNA/Nafion/GCE by using the selectivity study in the electrochemical investigation.
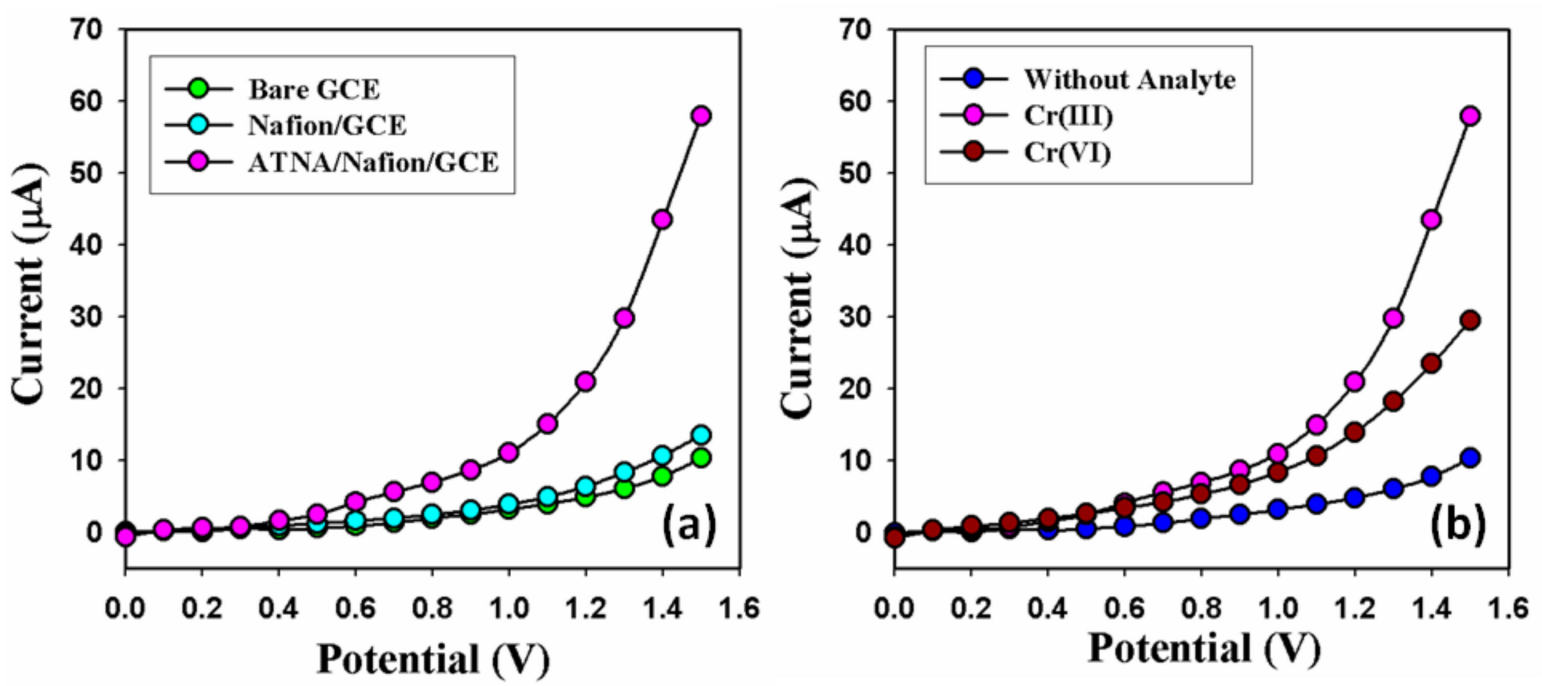

Figure 6. Control experiment: (a) the electrochemical responses of the bare GCE and the Nafion-coated GCE; and (b) the electrochemical responses of ATNA/Nafion/GCE in the presence of $\mathrm{Cr}^{3+}$ and $\mathrm{Cr}(\mathrm{VI})$.

The ATNA Schiff base accommodates highly electronegative $e^{-}$-donating atoms, which were also confirmed by structure characterization through single-crystal X-ray diffraction analysis (Figures 1 and 2). It donates the electron pairs to $\mathrm{Cr}^{3+}$ ions, which results in a change in $(I-V)$ response as presented in the proposed mechanism (Scheme 4). It was also shown from the interference study that the ATNA Schiff base has a high affinity with $\mathrm{Cr}^{3+}$ ions in the company of other heavy metal cations. Moreover, the (I-V) response of newly designed ATNA/Nafion/GCE (as a selective as well as sensitive $\mathrm{Cr}^{3+}$ cationic electrochemical sensor) against the potential applied $(0-1.5 \mathrm{~V})$ become functional in the presence of $\mathrm{Cr}^{3+}$ ions. The current responses in the presence and absence of $\mathrm{Cr}^{3+}$ ions are shown in Scheme 4a-c. Upon adding a small amount $(25.0 \mu \mathrm{L}$ of $0.1 \mu \mathrm{M})$ of the target analyte $\left(\mathrm{Cr}^{3+}\right)$ in a PBS medium of $\mathrm{pH}=7$ through a digital micropipette, a marginal increase in the current response was observed due to the small surface of the modified GCE that was occupied by the $\mathrm{Cr}^{3+}$ ions. Therefore, the surface reaction continues and does not stop here. It proceeds continuously by increasing the concentration of the $\mathrm{Cr}^{3+}$ analytes onto the flat surface of the modified GCE in the system ( $\pi-\pi^{*}$ interaction), which gives the regular increment of a current response as a function of our target analytes. We can get a better idea from the concentration plot, Figure $7 \mathrm{a}$, which gives us an idea about the increase in the current response by increasing the concentration of $\mathrm{Cr}^{3+}$ in the system. Thus, the observed increase in the current response was in accordance with the occupation of the coated surface of modified GCE with the target analytes $\left(\mathrm{Cr}^{3+}\right)$ and at the end, the coated surface became saturated with $\mathrm{Cr}^{3+}$ ions as shown in Scheme $4 \mathrm{~d}$. Furthermore, it caused an increase in the $\pi-\pi^{*}$ interaction between the functional groups of ATNA and $\mathrm{Cr}^{3+}$ ions, which is responsible for the change 
in the current response, Scheme $4 \mathrm{~b}$. The same phenomena based on the above stipulated proposed mechanism for the detection of toxic chemicals have also been cited in the literature [59,60].
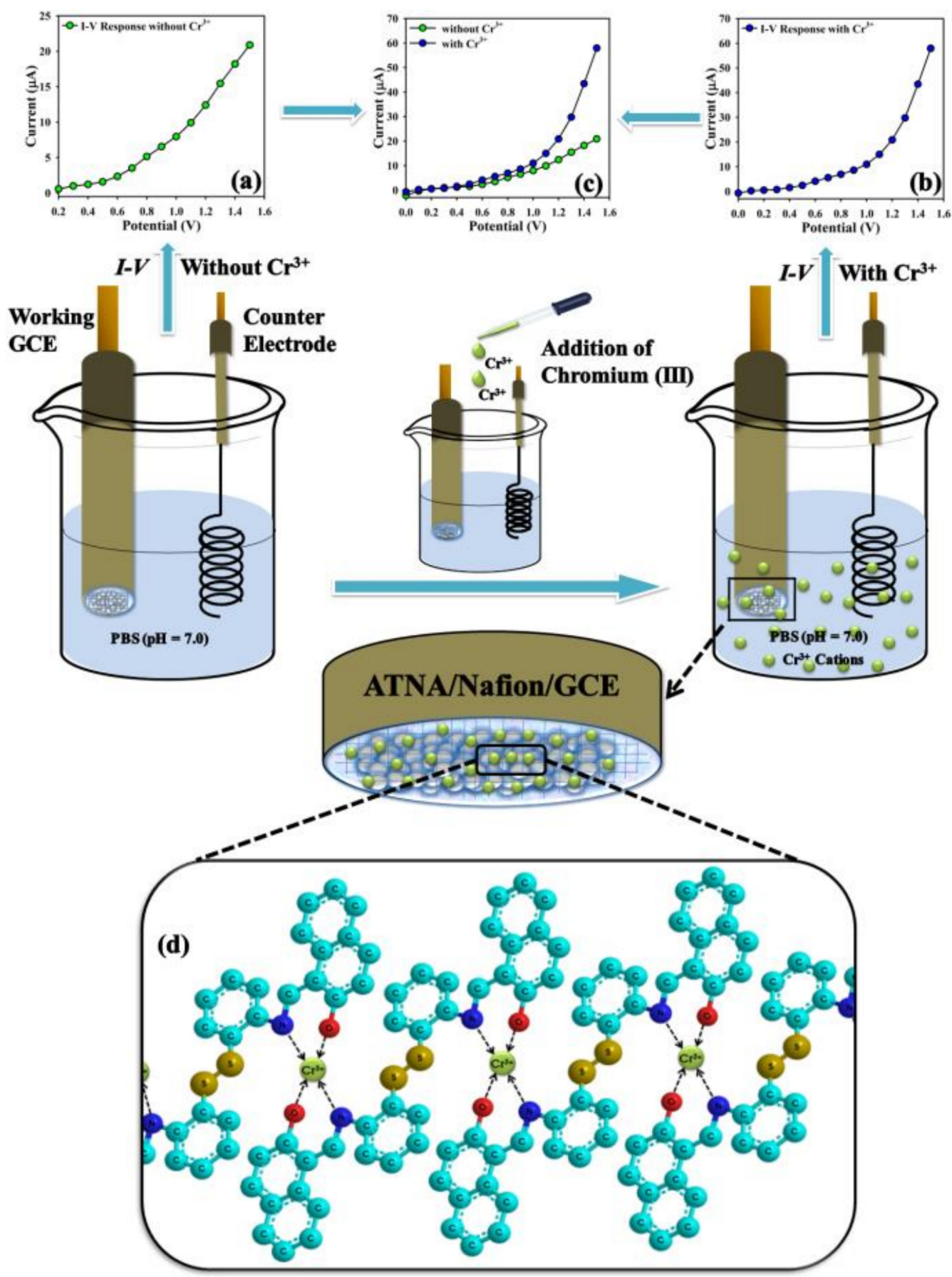

Scheme 4. Proposed mechanism of the probable interaction of $\mathrm{Cr}^{3+}$ with ATNA/Nafion/GCE: (a) the $I-V$ response without $\mathrm{Cr}^{3+} ;(\mathbf{b})$ the $I-V$ response with $\mathrm{Cr}^{3+}$; (c) the comparison of the I-V response with and without $\mathrm{Cr}^{3+}$; and (d) the probable $\pi-\pi^{*}$ interaction between the $\mathrm{Cr}^{3+}$ ions and ATNA.

In order to optimize the newly designed ATNA/Nafion/GCE as sensitive as well as a selective and efficient $\mathrm{Cr}^{3+}$ cationic electro-chemical sensor, a concentration variation plot was drawn at the different concentration range of $\mathrm{Cr}^{3+}$ analytes $(0.1 \mathrm{M}$ to $0.1 \mathrm{nM})$ in addition to the calibration curve at $+1.1 \mathrm{~V}$ from for above discussed concentration range of $\mathrm{Cr}^{3+}$ analytes, Figure 7a,b. It was observed that the current responses of ATNA/Nafion/GCE, as a selective cationic electrochemical $\mathrm{Cr}^{3+}$ sensor, 
progressively increased against the potential applied, from a lower to a higher value, as a function of $\mathrm{Cr}^{3+}$ concentration at standard temperature and pressure (STP), Figure 7a. Moreover, analytical parameters such as the LDR, LOD, LOQ, sensitivity, and the regression coefficient $\left(\mathrm{r}^{2}\right)$ were calculated from the calibration plot at $+1.1 \mathrm{~V}$ and these were found to be as $(0.1 \mathrm{nM}-10 \mathrm{mM}), 0.013 \mathrm{nM}, 0.044 \mathrm{nM}$, $0.0071202 \mu \mathrm{A \mu} \mathrm{M}^{-1} \mathrm{~cm}^{-2}$ and 0.9579 , respectively, Figure $7 \mathrm{~b}$.
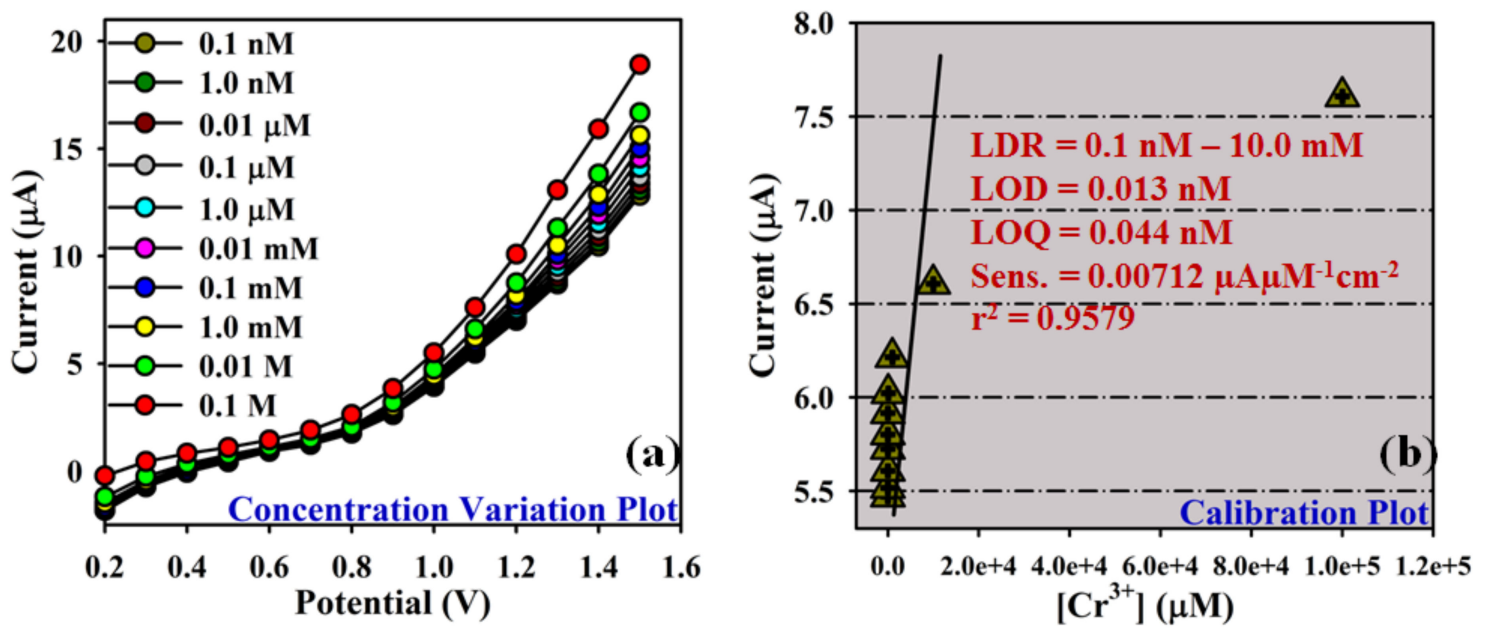

Figure 7. Optimization of the newly designed $\mathrm{Cr}^{3+}$ sensor: (a) the concentration variation plot of $\mathrm{Cr}^{3+}$ $(0.1 \mathrm{M}$ to $0.1 \mathrm{nM})$; and $(\mathbf{b})$ the calibration plot (at $+1.1 \mathrm{~V})$ of ATNA/Nafion/GCE.

Repeatability and response time, in addition to stability, were also checked in order to validate the newly designed ATNA/Nafion/GCE as an efficient electrochemical sensor. The repeatability test was conducted with successive nine to ten measurements of our target analyte $\left(\mathrm{Cr}^{3+}\right)$, which were taken as $0.25 \mu \mathrm{L}$ of $0.1 \mu \mathrm{M}$ of $\mathrm{Cr}^{3+}$ cations in each measurement, Figure 8a. In addition, a stability (reproducibility) test was also conducted and examined up to 17 days. It was found to be very stable with no significant change in the I-V response in addition to electrode poisoning and erosion up to 9 days, Figure $8 b$.
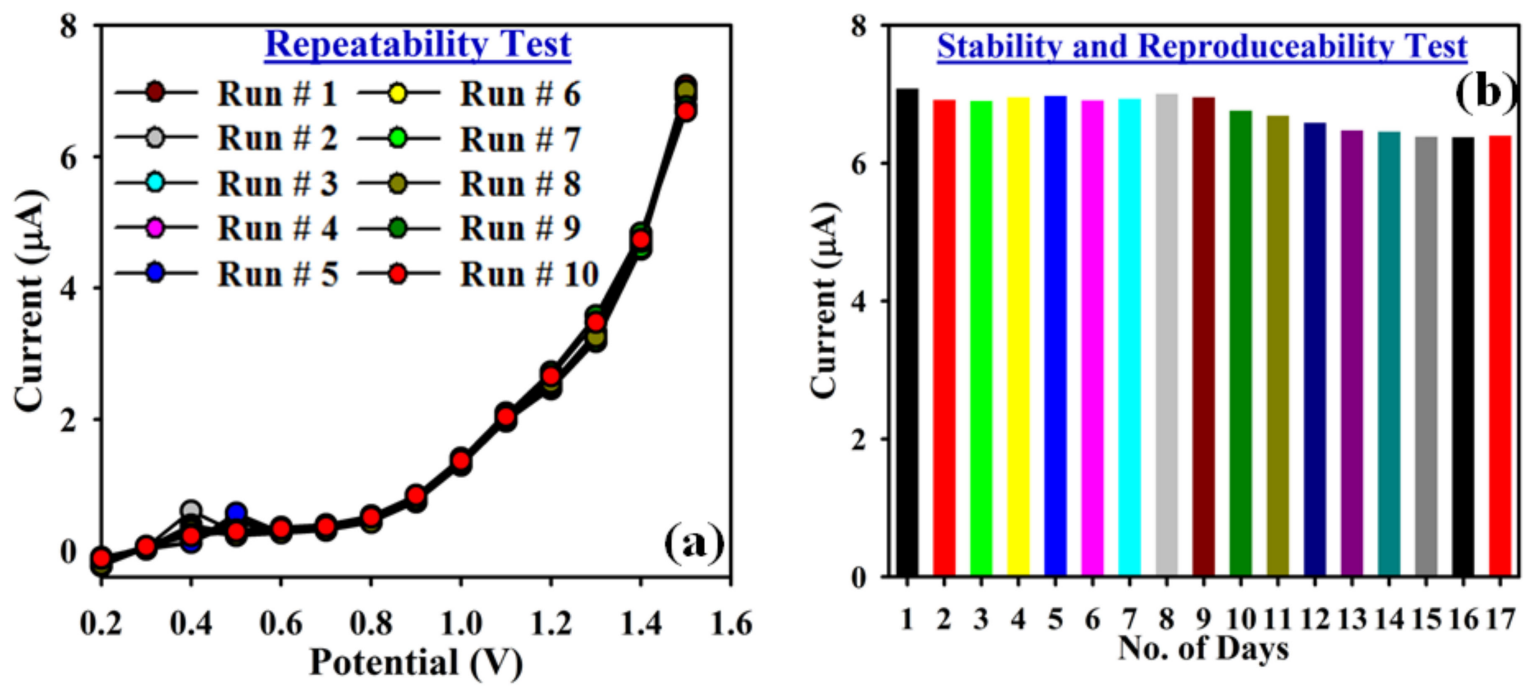

Figure 8. Repeatability and stability study: (a) the repeatability rest; and (b) the stability test of newly modified GCE (ATNA/Nafion/GCE as an efficient and sensitive $\mathrm{Cr}^{3+}$ cationic electrochemical sensor).

Similarly, the response time of the modified GCE was recorded (as current ( $\mu \mathrm{A})$ versus (s) time), and it was found to be very sensitive with a fast response in a short time that was from 10 to $20 \mathrm{~s}$. It was 
also noticed that it gave a good current response at $\mathrm{pH}=7$ against the potential applied $(0-1.5 \mathrm{~V})$ at a $1.0 \mathrm{~s}$ delay time as the scan rate, compared to the other scan rates in the presence of $\mathrm{Cr}^{3+}$, Figure $9 \mathrm{a}, \mathrm{b}$.
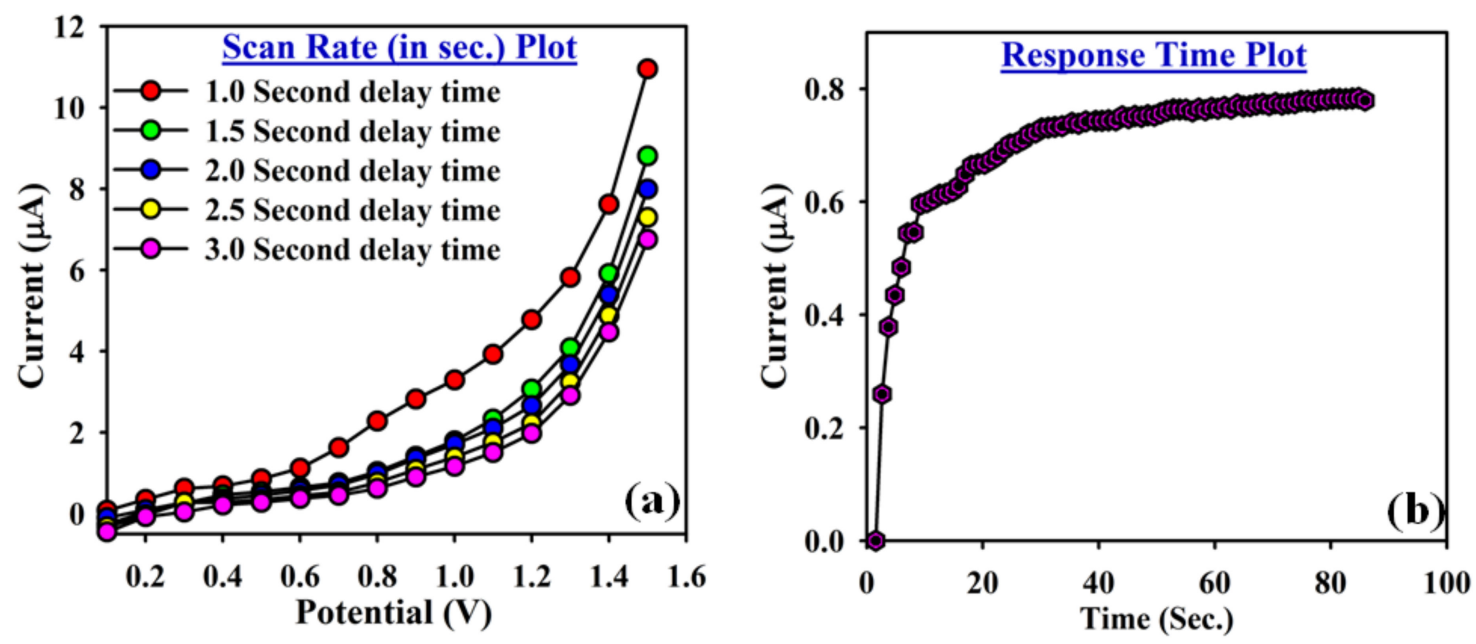

Figure 9. Response time: (a) the evaluation of the scan rates against the potential applied (0-1.5 V); and (b) the response time from 10 to $20 \mathrm{~s}$ to reach the saturated steady state.

The above conducted experiments enlighten us that the sensitivity of the newly designed ATNA/Nafion/GCE as a selective $\mathrm{Cr}^{3+}$ cationic electrochemical sensor is correlated with the adsorption as well as the absorption ability of the target analyte $\left(\mathrm{Cr}^{3+}\right)$ on to the surface of the modified GCE. It also depends on the affinity of the homobifunctional tridentate Schiff base with $\mathrm{Cr}^{3+}$ ions in addition to the high electronic communication feature which exists among the active sites of ATNA and $\mathrm{Cr}^{3+}$ ions. Moreover, the sensitivity and detection limits were also in good accordance as compared to the previous methods that have been reported in the literature, Table 4 . This current study also introduces a very simple, reliable approach to a significant extent for the optimistic detection of toxic chemicals in an aqueous media/solution in an ideal environmental and different care fields by using the newly designed ATNA as a tridentate homobifunctional disulphide Schiff base as a cationic electrochemical sensor. The obtained sensor analytical results exhibited the higher sensitivity and lower detection limit as well as the short response time as compared to other sensors fabricated with other materials for heavy metal ions in recent reports [61-64]. This is an initial report for the qualitative as well as the quantitative detection of $\mathrm{Cr}^{3+}$ ions by the electrochemical current-potential (I-V) approach based on newly modified GCE (ATNA/Nafion/GCE). 
Table 4. Comparison of the proposed $I-V$ method with different previously reported analytical methods for the detection of $\mathrm{Cr}^{3+}$.

\begin{tabular}{|c|c|c|c|c|c|c|}
\hline Methods & Material & Sensitivity & ${ }^{*}$ LDR & ${ }^{*}$ LOD & ${ }^{\circledR} \mathrm{LOQ}$ & Ref. \\
\hline Amperometric & Tyrosinase biosensor & - & $2.0 \times 10^{-4} \mathrm{M}$ & $500.0 \mathrm{nM}$ & - & [48] \\
\hline Capillary electrophoresis & 1,2-Cyclohexanediaminetetraacetic acid (CDTA) & - & $0.0 \mathrm{M}-0.0019 \mathrm{M}$ & $961.6 \mathrm{nM}$ & - & [40] \\
\hline Capillary electrophoresis & Hexamolybdochromate & - & $5 \times 10^{-6}-1 \times 10^{-5} \mathrm{M}$ & $2000 \mathrm{nM}$ & - & [41] \\
\hline Chemiluminescence & Ethylene diamine tetra acetate (EDTA) & - & $0.0-1 \times 10^{-6} \mathrm{M}$ & $0.5 \mathrm{nM}$ & - & [42] \\
\hline $\begin{array}{l}\text { Electrothermal atomic absorption } \\
\text { spectrometric }\end{array}$ & Nano $\mathrm{TiO}_{2}$ & - & $1 \times 10^{-3}-0.5 \mathrm{M}$ & $0.11 \mathrm{nM}$ & - & [27] \\
\hline $\begin{array}{l}\text { Thin-layer X-ray fluorescence } \\
\text { spectrometry }\end{array}$ & Solid-phase hydrous ferric hydroxide (HFO) & - & $0.0-1.0 \mu \mathrm{M}$ & $16.9 \mathrm{nM}$ & - & [36] \\
\hline $\begin{array}{l}\text { High-performance liquid } \\
\text { chromatography with diode-array } \\
\text { detection }\end{array}$ & Ammonium pyrrolidinedithiocarbamate (APDC) & - & $190 \mathrm{nM}-0.76 \mathrm{mM}$ & $76,900-134,000 \mathrm{nM}$ & - & [28] \\
\hline $\begin{array}{l}\text { Inductively Coupled } \\
\text { PlasmaAtomic-emission Spectrometry }\end{array}$ & Micro-column of activated alumina & - & $0.0-1.9 \times 10^{-5} \mathrm{M}$ & $26.0 \mathrm{nM}$ & - & [26] \\
\hline Electrochemical I-V method & ATNA/Nafion/GCE & $0.0071202 \mu \mathrm{A} \mu \mathrm{M}^{-1} \mathrm{~cm}^{-2}$ & $1.0 \mathrm{nM}-0.01 \mathrm{M}$ & $0.013 \mathrm{nM}$ & $0.04 \mathrm{nM}$ & This work \\
\hline
\end{tabular}

${ }^{*} \mathrm{LDR}=$ linear dynamic ranger; ${ }^{\#} \mathrm{LOD}=$ limit of detection; ${ }^{\circledR} \mathrm{LOQ}=$ limit of quantification 


\subsection{Real Sample Analysis}

The analysis of the real samples was also conducted by using this new proposed I-V approach through a standard addition method [15] so as to validate the newly modified GCE as an efficient and selective cationic electrochemical sensor for $\mathrm{Cr}^{3+}$ ion. A fixed quantity i.e., $25.0 \mu \mathrm{L}$ of each sample was investigated in PBS $(0.2 \mathrm{M}, \mathrm{pH}=7.0)$. Table 5 shows the results, which indicate that this proposed technique with newly modified GCE is also reliable for the investigation of $\mathrm{Cr}^{3+}$ in real samples.

Table 5. Real sample analysis of $\mathrm{Cr}^{3+}$ in various environmental samples.

\begin{tabular}{|c|c|c|c|c|c|c|c|c|}
\hline Real Samples & $\begin{array}{c}\text { Amount of } \\
\text { 3-CP Added }\end{array}$ & $\begin{array}{c}\text { No. of } \\
\text { Readings }\end{array}$ & $\begin{array}{c}\text { Measured } \\
\text { Response in }(\mu \mathrm{A})\end{array}$ & $\begin{array}{c}\% \\
\text { Recovery }\end{array}$ & $\begin{array}{c}\text { Mean } \\
\text { (\% Recovery) }\end{array}$ & SD & RSD & SEM \\
\hline $\mathrm{Cr}^{3+}$ & $\begin{array}{l}0.1 \mu \mathrm{M} \\
25 \mu \mathrm{L}\end{array}$ & - & 13.6808 & 100 & - & - & - & - \\
\hline \multirow{3}{*}{$\begin{array}{l}\text { Plastic baby } \\
\text { feeding bottle }\end{array}$} & \multirow{3}{*}{$\begin{array}{l}0.1 \mu \mathrm{M} \\
25 \mu \mathrm{L}\end{array}$} & R1 & 13.2376 & 96.7 & \multirow{3}{*}{91.2} & \multirow{3}{*}{4.765} & \multirow{3}{*}{5.22} & \multirow{3}{*}{2.75} \\
\hline & & R2 & 12.2129 & 89.3 & & & & \\
\hline & & R3 & 12.0183 & 87.8 & & & & \\
\hline \multirow{3}{*}{$\begin{array}{l}\text { Industrial } \\
\text { effluent }\end{array}$} & \multirow{3}{*}{$\begin{array}{l}0.1 \mu \mathrm{M} \\
25.0 \mu \mathrm{L}\end{array}$} & R1 & 14.9859 & 109.5 & \multirow{3}{*}{106.7} & \multirow{3}{*}{3.143} & \multirow{3}{*}{2.95} & \multirow{3}{*}{1.81} \\
\hline & & R2 & 14.6821 & 107.3 & & & & \\
\hline & & R3 & 14.1258 & 103.3 & & & & \\
\hline \multirow{3}{*}{ Sea water } & \multirow{3}{*}{$\begin{array}{l}0.1 \mu \mathrm{M}, \\
25.0 \mu \mathrm{L}\end{array}$} & R1 & 12.1036 & 88.5 & \multirow{3}{*}{88.1} & \multirow{3}{*}{1.833} & \multirow{3}{*}{2.08} & \multirow{3}{*}{1.05} \\
\hline & & $\mathrm{R} 2$ & 11.7748 & 86.1 & & & & \\
\hline & & R3 & 12.2757 & 89.7 & & & & \\
\hline \multirow{3}{*}{ Tap water } & \multirow{3}{*}{$\begin{array}{l}0.1 \mu \mathrm{M}, \\
25.0 \mu \mathrm{L}\end{array}$} & R1 & 13.2457 & 96.8 & \multirow{3}{*}{97.9} & \multirow{3}{*}{1.850} & \multirow{3}{*}{1.89} & \multirow{3}{*}{1.06} \\
\hline & & $\mathrm{R} 2$ & 13.6980 & 100.1 & & & & \\
\hline & & R3 & 13.2682 & 97.0 & & & & \\
\hline
\end{tabular}

$\mathrm{SD}$ = standard deviation; $\mathrm{RSD}$ = relative standard deviation; $\mathrm{SEM}$ = standard error of mean

\section{Conclusions}

A new electrochemical sensor for the selective detection of $\mathrm{Cr}^{3+}$ in aqueous solution based on homobifunctional tridentate disulfide Schiff base was presented for the first time. The conformation of ATNA as confirmed by the single crystal X-ray diffractions indicate that the imine bond $(\mathrm{C}=\mathrm{N})$ in both parts in the molecule is trans, favoring the molecule to stay in the most stable form. The molecule was stabilized by the $\mathrm{O}-\mathrm{H} \ldots \mathrm{N}$ type intramolecular hydrogen bonding interactions. The ATNA/Nafion/GCE as an efficient and sensitive electrochemical sensor for the detection of toxic cations in an aqueous solution by means of the electrochemical (I-V) approach was investigated. It was found to be very stable as well as sensitive against the $\mathrm{Cr}^{3+}$ ions in a short response time with a detection limit as low as $0.013 \mathrm{nM}$. Therefore, this study offers the new idea that can be used for the invention of newly non-reported cationic electrochemical sensors based on multidentate ligands or chelating agents for the investigation of heavy metals cations in commercially.

Supplementary Materials: The following are available online at http://www.mdpi.com/1996-1944/13/12/2695/s1.

Author Contributions: R.M.E., M.M.R., T.A.S., M.N.A., F.A.M.A., and A.M.A. contributed to the ideas, executed all the experiments, analyzed and interpreted the data, as well as the writing, reviewing and editing of the manuscript. All authors have read and agreed to the published version of the manuscript.

Funding: This work was supported by the Deanship of Scientific Research (DSR), King Abdulaziz University, Jeddah, under grant No. (DF-671-130-1441).

Acknowledgments: This project was funded by the Deanship of Scientific Research (DSR), King Abdulaziz University, Jeddah, under grant No. (DF-671-130-1441). The authors, therefore, gratefully acknowledge DSR technical and financial support.

Conflicts of Interest: The authors declare no conflict of interest. 


\section{References}

1. Word Health Organization. Organization, Guidelines for Drinking Water Quality; Word Health Organization: Geneva, Switzerland, 2011.

2. Rassaei, L.; Marken, F.; Sillanpää, M.; Amiri, M.; Cirtiu, C.M.; Sillanpää, M. Nanoparticles in electrochemical sensors for environmental monitoring. Trends Anal. Chem. 2011, 30, 1704-1715. [CrossRef]

3. Arvand, M.; Lashkari, Z. Sensitive and selective detection of trace copper in standard alloys, food and biological samples using a bulk optode based on $\mathrm{N}, \mathrm{N}^{\prime}-\left(4,4^{\prime}\right.$-ethylene biphenyl) bis(3-methoxy salicylidine imine) as neutral carrier. Spectrochim. Acta Part A 2013, 107, 280-288. [CrossRef] [PubMed]

4. Kara, D.; Fisher, A. Modified silica gels and their use for the preconcentration of trace elements. Sep. Purif. Rev. 2012, 41, 267-317. [CrossRef]

5. El-Shishtawy, R.M.; Mohamed, S.A.; Asiri, A.M.; Ahmed, N.S. Synthesis of hemicyanine-based chitosan ligands in dye-affinity chromatography for the purification of chewing stick peroxidase. Int. J. Biol. Macromol. 2020, 148, 401-414. [CrossRef]

6. Nafee, S.S.; Hagar, M.; Ahmed, H.A.; Alhaddad, O.; El-Shishtawy, R.M.; Raffah, B.M. New two rings Schiff base liquid crystals; ball mill synthesis, mesomorphic, Hammett and DFT studies. J. Mol. Liq. 2020, 299, 112161. [CrossRef]

7. Nafee, S.S.; Hagar, M.; Ahmed, H.A.; El-Shishtawy, R.M.; Raffah, B.M. The synthesis of new thermal stable schiff base/ester liquid crystals: A computational, mesomorphic, and optical study. Molecules 2019, 24, 3032. [CrossRef]

8. Hussein, M.A.; El-Shishtawy, R.M.; Obaid, A.Y.; Salam, M.A. Influence of single-walled carbon nanotubes on the performance of Poly(Azomethine-Ether) composite materials. Polym. Technol. Eng. 2017, 57, 1150-1163. [CrossRef]

9. Noureddin, S.A.; El-Shishtawy, R.M.; Al-Footy, K.O. Curcumin analogues and their hybrid molecules as multifunctional drugs. Eur. J. Med. Chem. 2019, 182, 111631. [CrossRef]

10. Zayed, M.E.; El-Shishtawy, R.M. Synthesis and antimicrobial activity of Aluminium(III), Nickel(II) and Zinc(II) schiff base complexes derived from o-phenylenediamine and salicylaldehyde. Asian J. Chem. 2013, 25, 2719-2721. [CrossRef]

11. Ando, R.; Ono, H.; Yagyu, T.; Maeda, M. Spectroscopic characterization of mononuclear, binuclear, and insoluble polynuclear oxovanadium(IV)-Schiff base complexes and their oxidation catalysis. Inorg. Chim. Acta 2004, 357, 817-823. [CrossRef]

12. Saravanamoorthy, S.; Sivan, V. Physiochemical interactions of chiral Schiff bases on high carbon steel surface: Corrosion inhibition in acidic media. Prog. Org. Coat. 2013, 76, 1527-1535. [CrossRef]

13. Aqlan, F.M.; Alam, M.; Asiri, A.M.; Zayed, M.E.; Al-Eryani, D.A.; Al-Zahrani, F.A.; El-Shishtawy, R.M.; Uddin, J.; Rahman, M.M. Fabrication of selective and sensitive $\mathrm{Pb}^{2+}$ detection by 2,2'-(-(1,2-phenylenebis (azaneylylidene))bis(methaneylylidene))diphenol by electrochemical approach for environmental remediation. J. Mol. Liq. 2019, 281, 401-406. [CrossRef]

14. El-Shishtawy, R.M.; Al-Ghamdi, H.A.; Alam, M.M.; Al-Amshany, Z.M.; Asiri, A.M.; Rahman, M.M. Development of $\mathrm{Cd}^{2+}$ sensor based on BZNA/Nafion/Glassy carbon electrode by electrochemical approach. Chem. Eng. J. 2018, 352, 225-231. [CrossRef]

15. Rahman, M.M.; Sheikh, T.A.; El-Shishtawy, R.M.; Arshad, M.N.; Al-Zahrani, F.A.M.; Asiri, A.M. Fabrication of $\mathrm{Sb}^{3+}$ sensor based on 1,1'-(-(naphthalene-2,3-diylbis(azanylylidene)) bis(methanylylidene))bis (naphthalen-2-ol)/nafion/glassy carbon electrode assembly by electrochemical approach. RSC Adv. 2018, 8, 19754-19764. [CrossRef]

16. Ramadan, R.; Elantabli, F.M.; El-Medani, S.M. Conversion of thiol to homodisulfide-Schiff base derivative: Synthesis, molecular structure, crystal structure and DFT studies. J. Mol. Struct. 2019, 1196, 547-554. [CrossRef]

17. Singh, A.; Gupta, V.; Gupta, B. Chromium(III) selective membrane sensors based on Schiff bases as chelating ionophores. Anal. Chim. Acta 2007, 585, 171-178. [CrossRef]

18. Vincent, J.B. Quest for the molecular mechanism of chromium action and its relationship to diabetes. Nutr. Rev. 2000, 58, 67-72. [CrossRef]

19. Latva, S.; Jokiniemi, J.; Peräniemi, S.; Ahlgrén, M. Separation of picogram quantities of Cr(III) and Cr(VI) species in aqueous solutions and determination by graphite furnace atomic absorption spectrometry. J. Anal. At. Spectrom. 2003, 18, 84-86. [CrossRef] 
20. McRae, R.; Bagchi, P.; Sumalekshmy, S.; Fahrni, C.J. In situ imaging of metals in cells and tissues. Chem. Rev. 2009, 109, 4780-4827. [CrossRef]

21. O'Brien, T.; Mandel, H.G.; Pritchard, D.E.; Patierno, S.R. Critical role of Chromium (Cr)-DNA interactions in the formation of Cr-induced polymerase arresting lesions. Biochemistry 2002, 41, 12529-12537. [CrossRef]

22. Zhitkovich, A.; Quievryn, G.; Messer, J.; Motylevich, Z. Reductive activation with cysteine represents a chromium(III)-dependent pathway in the induction of genotoxicity by carcinogenic chromium(VI). Environ. Health Perspect. 2002, 110, 729-731. [CrossRef] [PubMed]

23. Mondal, B. Synthesis and characterization of a new resin functionalized with 2-naphthol-3,6-disulfonic acid and its application for the speciation of chromium in natural water. Talanta 2002, 56, 145-152. [CrossRef]

24. Beinrohr, E.; Manova, A.; Dzurov, J. Preconcentration of $\mathrm{Cr}$ (III) and total $\mathrm{Cr}$ in waters for flame AAS in a flow-through electrochemical/sorption cell. Anal. Bioanal. Chem. 1996, 355, 528-531. [CrossRef] [PubMed]

25. Posta, J.; Berndt, H.; Luo, S.K.; Schaldach, G. High-performance flow flame atomic absorption spectrometry for automated on-line separation and determination of chromium (III)/chromium (VI) and preconcentration of chromium (VI). Anal. Chem. 1993, 65, 2590-2595. [CrossRef]

26. Cox, A.G.; Cook, I.G.; McLeod, C. Rapid sequential determination of chromium(III)-chromium(VI) by flow injection analysis-inductively coupled plasma atomic-emission spectrometry. Analyst 1985, 110, 331. [CrossRef]

27. Wu, P.; Chen, H.; Cheng, G.; Hou, X. Exploring surface chemistry of nano-TiO2 for automated speciation analysis of $\mathrm{Cr}$ (iii) and $\mathrm{Cr}(\mathrm{vi})$ in drinking water using flow injection and ET-AAS detection. J. Anal. At. Spectrom. 2009, 24, 1098. [CrossRef]

28. Cathum, S.; Brown, C.; Wong, W. Determination of $\mathrm{Cr}^{3+}, \mathrm{CrO}_{4}{ }^{2-}$, and $\mathrm{Cr}_{2} \mathrm{O}_{7}{ }^{2-}$ in environmental matrixes by high-performance liquid chromatography with diode-array detection (HPLC-DAD). Anal. Bioanal. Chem. 2002, 373, 103-110. [CrossRef]

29. Krull, I.S.; Bushee, D.; Savage, R.N.; Schleicher, R.G.; Smith, S.B., Jr. Speciation of Cr (III) and Cr (VI) via reversed phase HPLC with inductively coupled plasma emission spectroscopic detection (HPLC-ICP) 24. Anal. Lett. 1982, 15, 267-281. [CrossRef]

30. Bond, A.M.; Wallace, G.G. Simultaneous determination of copper, nickel, cobalt, chromium(VI), and chromium(III) by liquid chromatography with electrochemical detection. Anal. Chem. 1982, 54, 1706-1712. [CrossRef]

31. Wang, H.-J.; Du, X.-M.; Wang, M.; Wang, T.-C.; Ou-Yang, H.; Wang, B.; Zhu, M.-T.; Wang, Y.; Jia, G.; Feng, W.; et al. Using ion-pair reversed-phase HPLC ICP-MS to simultaneously determine $\mathrm{Cr}(\mathrm{III})$ and $\mathrm{Cr}(\mathrm{VI})$ in urine of chromate workers. Talanta 2010, 81, 1856-1860. [CrossRef]

32. Jen, J.-F.; Ou-Yang, G.-L.; Chen, C.-S.; Yang, S.-M. Simultaneous determination of chromium(III) and chromium (VI) with reversed-phase ion-pair high-performance liquid chromatography. Analyst 1993, 118, 1281. [CrossRef]

33. Bittner, M.; Broekaert, J. Speciation of chromium by solid-phase extraction coupled to reversed-phase liquid chromatography with UV detection. Anal. Chim. Acta 1998, 364, 31-40. [CrossRef]

34. Gürleyük, H.; Wallschläger, D. Determination of chromium(iii) and chromium(vi) using suppressed ion chromatography inductively coupled plasma mass spectrometry. J. Anal. At. Spectrom. 2001, 16, 926-930. [CrossRef]

35. Michalski, R. Trace level determination of $\mathrm{Cr}$ (III)/Cr (VI) in water samples using ion chromatography with UV detection. J. Liq. Chromatogr. Relat. Technol. 2005, 28, 2849-2862. [CrossRef]

36. Hettipathirana, T.D. Speciation of sub-parts per billion levels of $\mathrm{Cr}$ (III) in waters by solid-phase adsorption followed by thin-layer X-ray fluorescence spectrometry. X-Ray Spectrom. 2001, 30, 330-337. [CrossRef]

37. Elavarasi, M.; Alex, S.A.; Chandrasekaran, N.; Mukherjee, A. Simple fluorescence-based detection of Cr(iii) and $\mathrm{Cr}(\mathrm{vi})$ using unmodified gold nanoparticles. Anal. Methods 2014, 6, 9554-9560. [CrossRef]

38. Wang, N.; Shiraishi, Y.; Hirai, T. A distyryl BODIPY derivative as a fluorescent probe for selective detection of chromium(III). Tetrahedron Lett. 2010, 51, 2545-2549. [CrossRef]

39. Dong, C.; Wu, G.; Wang, Z.; Ren, W.; Zhang, Y.; Shen, Z.; Li, T.; Wu, A. Selective colorimetric detection of Cr(iii) and Cr(vi) using gallic acid capped gold nanoparticles. Dalton Trans. 2016, 45, 8347-8354. [CrossRef]

40. Timerbaev, A.R.; Semenova, O.; Buchberger, W.; Bonn, G.K. Speciation studies by capillary electrophoresisSimultaneous determination of chromium(III) and chromium(VI). Anal. Bioanal. Chem. 1996, 354, 414-419. [CrossRef] 
41. Himeno, S.; Nakashima, Y.; Sano, K.-I. Simultaneous determination of Chromium(VI) and Chromium(III) by capillary electrophoresis. Anal. Sci. 1998, 14, 369-373. [CrossRef]

42. Seitz, W.R.; Suydam, W.W.; Hercules, D.M. Determination of trace amounts of chromium(III) using chemiluminescence analysis. Anal. Chem. 1972, 44, 957-963. [CrossRef]

43. Stefan, R.-I.; Bairu, S.G.; Van Staden, J.F. Diamond paste-based electrodes for determination of Cr(III) in pharmaceutical compounds. Anal. Bioanal. Chem. 2003, 376, 844-847. [CrossRef] [PubMed]

44. Vukomanovic, D.V.; VanLoon, G.W.; Nakatsu, K.; Zoutman, D.E. Determination of Chromium (VI) and (III) by adsorptive stripping voltammetry with pyrocatechol violet. Microchem. J. 1997, 57, 86-95. [CrossRef]

45. Jin, W.; Wu, G.; Chen, A. Sensitive and selective electrochemical detection of chromium(vi) based on gold nanoparticle-decorated titania nanotube arrays. Analyst 2014, 139, 235-241. [CrossRef] [PubMed]

46. Paniagua, A.R.; Vazquez, M.D.; Tascon, M.L.; Batanero, P.S. Determination of chromium(VI) and chromium(III) by using a diphenylcarbazide-modified carbon paste electrode. Electroanalysis 1993, 5, 155-163. [CrossRef]

47. Metters, J.P.; Kadara, R.O.; Banks, C.E. Electroanalytical sensing of chromium(iii) and (vi) utilising gold screen printed macro electrodes. Analyst 2012, 137, 896. [CrossRef]

48. Renedo, O.D.; Lomillo, M.A.A.; Martinez, M.J.A. Optimisation procedure for the inhibitive determination of chromium (III) using an amperometrictyrosinase biosensor. Anal. Chim. Acta 2004, 521, 215-221. [CrossRef]

49. Agilent. CrysAlis PRO; Agilent Technologies: Yarnton, UK, 2012.

50. Sheldrick, G.M. A short history ofSHELX. Acta Crystallogr. A 2007, 64, 112-122. [CrossRef]

51. Farrugia, L.J. WinGX and ORTEP for Windows: An update. J. Appl. Crystallogr. 2012, 45, 849-854. [CrossRef]

52. Spek, A.L. PLATON-a Multipurpose Crystallographic Tool; Utrecht University: Utrecht, The Netherlands, 2005.

53. Farrugia, L.J. WinGX suite for small-molecule single-crystal crystallography. J. Appl. Crystallogr. 1999, 32, 837-838. [CrossRef]

54. Denes, F.; Pichowicz, M.; Povie, G.; Renaud, P. Thiyl radicals in organic synthesis. Chem. Rev. 2014, 114, 2587-2693. [CrossRef] [PubMed]

55. Moosavi-Tekyeh, Z.; Dastani, N. Intramolecular hydrogen bonding in N-salicylideneaniline: FT-IR spectrum and quantum chemical calculations. J. Mol. Struct. 2015, 1102, 314-322. [CrossRef]

56. Coates, J. Interpretation of infrared spectra, a practical approach. In Encyclopedia of Analytical Chemistry; Wiley: Hoboken, NJ, USA, 2006; pp. 10815-11083.

57. Raj, P.; Singh, A.; Singh, N.; Singh, N. Syntheses and photophysical properties of schiff base Ni(II) complexes: Application for sustainable antibacterial activity and cytotoxicity. Chem. Eng. 2017, 5, 6070-6080. [CrossRef]

58. Bernstein, J.; Davis, R.E.; Shimoni, L.; Chang, N.-L. Patterns in hydrogen bonding: Functionality and graph set analysis in crystals. Angew. Chem. Int. Ed. 1995, 34, 1555-1573. [CrossRef]

59. Sheikh, T.A.; Arshad, M.N.; Asiri, A.M.; Rahman, M.M.; Shaikh, T.A. Development of a selective and sensitive $\mathrm{Ga}^{3+}$ sensor for environmental safety: A comparative study of cyclohexyl and aromatic bis-sulphonamide fabricated glassy carbon electrodes. New J. Chem. 2018, 42, 13589-13601. [CrossRef]

60. Sheikh, T.A.; Arshad, M.N.; Rahman, M.M.; Asiri, A.M.; Marwani, H.M.; Awual, R.; Bawazir, W.A. Trace electrochemical detection of $\mathrm{Ni}^{2+}$ ions with bidentate $\mathrm{N}, \mathrm{N}^{\prime}$-(ethane-1, 2-diyl) bis (3, 4-dimethoxy benzenesulfonamide)[EDBDMBS] as a chelating agent. Inorg. Chim. Acta 2017, 464, 157-166. [CrossRef]

61. Hussain, M.M.; Asiri, A.M.; Arshad, M.N.; Rahman, M.M. Synthesis, characterization, and crystal structure of (E)-N'-(4-Bromobenzylidene)-benzenesulfonohydrazide and its application as a sensor of chromium ion detection from environmental samples. J. Mol. Struct. 2020, 1207, 127810. [CrossRef]

62. Khan, A.; Khan, A.A.P.; Rahman, M.M.; Asiri, A.M.; Alamry, K. Preparation of polyaniline grafted graphene oxide-WO3 nanocomposite and its application as a chromium(iii) chemi-sensor. RSC Adv. 2015, 5, 105169-105178. [CrossRef]

63. Asiri, A.M.; BahadarKhanab, S.; Alamry, K.; Marwani, H.; Rahman, M.M. Growth of $\mathrm{Mn}_{3} \mathrm{O}_{4}$ on cellulose matrix: Nanohybrid as a solid phase adsorbent for trivalent chromium. Appl. Surf. Sci. 2013, 270, 539-544. [CrossRef]

64. Rahman, M.M.; Balkhoyor, H.B.; Asiri, A.M. Phenolic sensor development based on chromium oxide-decorated carbon nanotubes for environmental safety. J. Environ. Manag. 2017, 188, 228-237. [CrossRef]

(C) 2020 by the authors. Licensee MDPI, Basel, Switzerland. This article is an open access article distributed under the terms and conditions of the Creative Commons Attribution (CC BY) license (http://creativecommons.org/licenses/by/4.0/). 